\title{
Genome-wide association between single nucleotide polymorphisms with beef fatty acid profile in Nellore cattle using the single step procedure
}

Marcos V. A. Lemos ${ }^{1 *}$, Hermenegildo Lucas Justino Chiaia ${ }^{1}$, Mariana Piatto Berton ${ }^{1}$, Fabieli L. B. Feitosa ${ }^{1}$,

Carolyn Aboujaoud', Gregório M. F. Camargo', Angélica S. C. Pereira², Lucia G. Albuquerque', Adrielle M. Ferrinho², Lenise F. Mueller ${ }^{2}$, Monica R. Mazalli', Joyce J. M. Furlan², Roberto Carvalheiro', Daniel M. Gordo ${ }^{1}$, Rafael Tonussi', Rafael Espigolan', Rafael Medeiros de Oliveira Silva', Henrique Nunes de Oliveira', Susan Duckett ${ }^{3}$, Ignacio Aguilar ${ }^{4}$ and Fernando Baldi ${ }^{1}$

\begin{abstract}
Background: Saturated fatty acids can be detrimental to human health and have received considerable attention in recent years. Several studies using taurine breeds showed the existence of genetic variability and thus the possibility of genetic improvement of the fatty acid profile in beef. This study identified the regions of the genome associated with saturated, mono- and polyunsaturated fatty acids, and n-6 to n-3 ratios in the Longissimus thoracis of Nellore finished in feedlot, using the single-step method.

Results: The results showed that 115 windows explain more than $1 \%$ of the additive genetic variance for the 22 studied fatty acids. Thirty-one genomic regions that explain more than $1 \%$ of the additive genetic variance were observed for total saturated fatty acids, C12:0, C14:0, C16:0 and C18:0. Nineteen genomic regions, distributed in sixteen different chromosomes accounted for more than $1 \%$ of the additive genetic variance for the monounsaturated fatty acids, such as the sum of monounsaturated fatty acids, C14:1 cis-9, C18:1 trans-11, C18:1 cis-9, and C18:1 trans-9. Forty genomic regions explained more than $1 \%$ of the additive variance for the polyunsaturated fatty acids group, which are related to the total polyunsaturated fatty acids, C20:4 n-6, C18:2 cis-9 cis12 n-6, C18:3 n-3, C18:3 n-6, C22:6 n-3 and C20:3 n-6 cis-8 cis-11 cis-14. Twenty-one genomic regions accounted for more than $1 \%$ of the genetic variance for the group of omega-3, omega- 6 and the $n-6: n-3$ ratio.
\end{abstract}

Conclusions: The identification of such regions and the respective candidate genes, such as ELOVL5, ESSRG, PCYT1A and genes of the $A B C$ group ( $A B C 5, A B C 6$ and $A B C 10)$, should contribute to form a genetic basis of the fatty acid profile of Nellore (Bos indicus) beef, contributing to better selection of the traits associated with improving human health.

Keywords: Bos indicus, Fatty acid composition, Heritability, Genetic markers, Mapping, ssGWAS

\footnotetext{
* Correspondence: marcoslemoszootec@gmail.com

1Departamento de Zootecnia, Faculdade de Ciências Agrárias e Veterinárias, Universidade Estadual Paulista, Via de acesso Prof. Paulo Donato Castellane, s/no, CEP 14884-900 Jaboticabal, São Paulo, Brazil

Full list of author information is available at the end of the article
} 


\section{Background}

High consumption of saturated fatty acids (SFA) is associated with increased serum levels of cholesterol and low-density lipoproteins (LDL), considered risk factors for the occurrence of cardiovascular disease [1]. The SFAs prevalent in beef fat are the myristic (C14:0), palmitic (C16:0) and stearic (C18:0) fatty acids [2, 3]. The polyunsaturated fatty acids (PUFA) present in beef, such as linoleic (C18:2 n-6) and linolenic (C18:3 n-3), and monounsaturated (MUFA), as oleic acid (C18:1 n-9) protect the cardiovascular system, since moderate consumption has been linked to decreasing serum cholesterol and increasing high-density lipoprotein (HDL) [4-6].

Furthermore, the fat of ruminants is a natural source of conjugated isomers of linoleic acid (CLA c9 t11), such as C18:2 cis-9 trans-11 [7], which are synthesized in the rumen as a result of biohydrogenation of fatty acids, performed by microorganisms [8]. The CLAs have a positive effect on human health, related to anticancer activity, immune functions, and potential beneficial effects on coronary heart disease $[9,10]$. Strategies such as diet [11] and gene manipulation [12] have been used to satisfy the growing consumer demand for protein sources with healthier lipid profile. Thus, regions associated with the expression of beef fatty acid profile have been identified aiming to locate key genes in the genome [13-15] that contribute to these features. This genomic tool will assist the use of information that is beneficial to human health.

Recently, several genome-wide association studies using taurine breeds and their crosses [16-19] have identified genetic variants for fatty acid (FA) profile in beef. These results would allow producers to select for desirable nutritional values with respect to meat FA that could increase beef value and consumer satisfaction. However, there are limited number of genomic association studies with a large sample size that aim to determine genome regions associated with the meat fatty acid profile of zebu cattle reared in tropical conditions [3]. The study of [3] utilized 386 Nellore steers, sired from 34 unrelated sires, from an experimental herd, and applied the Bayes $B$ method to perform the genome-wide association analysis. In the literature, there is some controversy regarding the capacity of different methods to identify genomic regions related to phenotypes due to differences in method presuppositions [20-22]. Moreover, it is important to perform genome-wide association studies (GWAS) in indicine populations due to differences in environment and management conditions, and also differences in allele frequency of genetic markers and QTL, that would influence the results. The identification of genomic regions that affect the meat fatty acid composition may become an important and highly applicable tool to improve the nutritional value of zebu meat given the expensive and difficult nature of collecting phenotypic records.

The objective of this study was to identify regions associated with saturated, mono- and polyunsaturated and n-6 to n-3 ratios, in the Longissimus thoracis muscle from confined Nellore, using the single-step method.

\section{Results and discussion}

\section{Fatty acid profile}

The individual fatty acids with the highest concentration in the intramuscular fat of Longissimus thoracis were C16:0, C18:1 cis-9, C18:1 trans-11, and C18:0, representing $67.3 \%$ of its fat composition (Table 1 ). These results agreed with those reported by some authors [2, 13, 23, 24] who observed high levels of palmitic, stearic and oleic FAs. Some authors [2, 3] also reported that palmitic fatty acid was the predominant FA in beef fat. In Nellore finished in feedlot [13], oleic acid (37.46\%) displayed the highest concentration in intramuscular fat. The myristic and palmitic FAs are associated with an increase in circulating LDL cholesterol due to interference with hepatic

Table 1 Descriptive statistics for the fatty acids profile of Nellore beef $^{a}$

\begin{tabular}{|c|c|c|c|c|}
\hline Trait & Nomenclature & Mean & ${ }^{\mathrm{b}} \mathrm{SD}$ & ${ }^{\mathrm{c} N}$ \\
\hline Intramuscular fat & IMF (in percentage) & 0.83 & 0.42 & 934 \\
\hline Lauric & $\mathrm{C} 12: 0$ & 0.06 & 0.18 & 538 \\
\hline Myristic & C14:0 & 2.13 & 0.54 & 867 \\
\hline Myristoleic & C14:1 & 0.32 & 0.22 & 824 \\
\hline Palmitic & C16:0 & 21.03 & 2.49 & 867 \\
\hline Palmitoleic & C16:1 & 2.18 & 0.78 & 937 \\
\hline Stearic & C18:0 & 13.63 & 3.32 & 783 \\
\hline Elaidic & C18:1n9t & 2.91 & 5.07 & 483 \\
\hline Oleic & C18:1n9c & 30.64 & 4.98 & 934 \\
\hline Vaccenic (TVA) & $\mathrm{C} 18: 1 \mathrm{t} 11$ & 1.29 & 0.01 & 878 \\
\hline Linoleic (LA) & C18:2n6 & 8.32 & 3.63 & 865 \\
\hline Linolenic & C18:3n3 & 0.59 & 0.26 & 858 \\
\hline CLA-cis & C18:2c9t11 & 0.26 & 0.16 & 727 \\
\hline CLA-trans & $\mathrm{C} 18: 2$ trans 10 cis 12 & 0.20 & 0.12 & 241 \\
\hline Docosahexaenoic (DHA) & $\mathrm{C} 22: 6 \mathrm{n} 3$ & 0.95 & 0.39 & 865 \\
\hline Eicosatrienoic & C20:3 n6 cis-8,11,14 & 0.49 & 0.19 & 862 \\
\hline Sum of SFA & & 40.66 & 6.12 & 868 \\
\hline Sum of MUFA & & 37.55 & 8.05 & 868 \\
\hline Sum of PUFA & & 13.42 & 5.57 & 868 \\
\hline Sum of Omega-3 & & 3.81 & 1.55 & 868 \\
\hline Sum of Omega- 6 & & 9.35 & 4.44 & 868 \\
\hline n6/n3 ratio & & 2.54 & 0.97 & 868 \\
\hline PUFA/SFA ratio & & 0.35 & 0.20 & 868 \\
\hline
\end{tabular}

${ }^{a}$ The concentration of fatty acids are expressed as a percentage of total fatty acid methyl esters (FAME) quantified ${ }^{b} S D$ standard deviation ${ }^{c} N$ number of animals with records 
LDL receptors [25]. The saturated fatty acid were predominant, followed by the MUFAs and PUFAs. Similar results [23] were reported for Nellore cattle, $43.93 \%$ (SFA), $42.33 \%$ (MUFA) and $12.8 \%$ (PUFA). However, studies using taurine [26] and Nellore [13] breeds found similar concentrations for SFA and MUFA, 47 and 47.5; and 47.23 , and $48.34 \%$, respectively.

In the present study, the $n-6: n-3$ ratio was less than $4: 1$, the value recommended by the Department of Health and some authors [27, 28]. Excessive amounts of n-6 and a high n-6:n-3 ratio can lead to pathogenies, including cardiovascular, inflammatory, cancer and autoimmune diseases while increased levels of omega- 3 fatty acids help to suppress such effects [29]. Studies have associated a $4: 1$ ratio to $70 \%$ decrease in mortality of humans, and also to preventing cardiovascular diseases [30]. The Department of Health recommends values above 0.45 for the PUFA/SFA ratio. The average value for this ratio in this study is below this limit (0.35). A PUFA/SFA ratio of 0.11 has been reported in beef purchased at supermarkets in the UK [31]. However, this
PUFA/SFA ratio may vary depending upon genetic and dietary factors [12].

\section{Heritability estimates}

The Gibbs sampling approach was used to estimate de (co)variance components and the convergence for all estimated parameters was verified through inspection of trace-plots and the Geweke's [32] and Heidelberger and Welch convergence diagnostic [33] indicated convergence of the chain. Thus, the burn-in period considered was sufficient to reach the convergence in all parameter estimates. The posterior marginal distributions of heritability estimates for fatty acid profile, presented showed accurate values, tending to normal distribution (Table 2). The symmetric distributions of central tendency statistics are indicative that the analyses are reliable.

The heritability estimates for the individual fatty acids profile of intramuscular fat in the Longissimus thoracis muscle were mostly moderate, but low for the C18:0, C16:1 and CLA cis-9 trans-11 acids and high for the C12:0 and CLA trans-10 cis-12 acids (Table 2). The

Table 2 Descriptive statistics and highest posterior density (HPD) region for fatty acid heritability estimates

\begin{tabular}{|c|c|c|c|c|c|c|}
\hline \multirow[t]{2}{*}{ Trait } & \multirow[t]{2}{*}{ Nomenclature } & \multirow[t]{2}{*}{ Mean } & \multirow[t]{2}{*}{ Median } & \multirow[t]{2}{*}{$S D^{a}$} & \multicolumn{2}{|l|}{ HPD } \\
\hline & & & & & Low limit & Upper limit \\
\hline Lauric & C12:0 & 0.64 & 0.69 & 0.24 & 0.17 & 0.99 \\
\hline Myristic & C14:0 & 0.27 & 0.26 & 0.10 & 0.04 & 0.46 \\
\hline Palmitic & C16:0 & 0.20 & 0.19 & 0.09 & 0.03 & 0.38 \\
\hline Stearic & C18:0 & 0.12 & 0.11 & 0.09 & 0.001 & 0.30 \\
\hline Myristoleic & C14:1 & 0.17 & 0.28 & 0.09 & 0.0003 & 0.62 \\
\hline Palmitoleic & C16:1 & 0.08 & 0.07 & 0.06 & 0.0002 & 0.21 \\
\hline Elaidic & C18:1 n9t & 0.24 & 0.21 & 0.16 & 0.006 & 0.57 \\
\hline Oleic & C18:1 n9c & 0.28 & 0.16 & 0.10 & 0.08 & 0.48 \\
\hline Vaccenic (TVA) & C18:1 trans- 11 & 0.11 & 0.14 & 0.06 & 0.003 & 0.24 \\
\hline Linoleic (LA) & $\mathrm{C} 18: 2 \mathrm{n} 6$ & 0.18 & 0.17 & 0.08 & 0.04 & 0.34 \\
\hline Linolenic acid (LA) & $\mathrm{C} 18: 3 \mathrm{n} 3$ & 0.15 & 0.15 & 0.08 & 0.02 & 0.31 \\
\hline Eicosatrienoic & C20:3 n6 cis-8, 11,14 & 0.14 & 0.13 & 0.09 & 0.02 & 0.31 \\
\hline Docosahexaenoic acid (DHA) & $\mathrm{C} 22: 6 \mathrm{n} 3$ & 0.15 & 0.14 & 0.10 & 0.01 & 0.32 \\
\hline \multirow[t]{2}{*}{ CLA } & Cis9 Trans-11 & 0.09 & 0.08 & 0.06 & 0.004 & 0.21 \\
\hline & Trans10 Cis-12 & 0.52 & 0.54 & 0.27 & 0.02 & 0.94 \\
\hline Arachidonic acid & C20:4 n-6 & 0.14 & 0.11 & 0.11 & 0.0007 & 0.38 \\
\hline Total of SFA & & 0.12 & 0.12 & 0.07 & 0.0001 & 0.31 \\
\hline Total of MUFA & & 0.20 & 0.12 & 0.15 & 0.0005 & 0.31 \\
\hline Total of PUFA & & 0.08 & 0.11 & 0.05 & 0.0009 & 0.32 \\
\hline Omega-3 & & 0.11 & 0.09 & 0.07 & 0.00008 & 0.29 \\
\hline Omega-6 & & 0.23 & 0.11 & 0.10 & 0.0001 & 0.31 \\
\hline Omega-9 & & 0.20 & 0.17 & 0.14 & 0.0002 & 0.46 \\
\hline Omega-6/omega-3 ratio & & 0.11 & 0.09 & 0.08 & 0.002 & 0.70 \\
\hline PUFA/SFA ratio & & 0.07 & 0.06 & 0.05 & 0.0001 & 0.17 \\
\hline
\end{tabular}

${ }^{\mathrm{a}} \mathrm{SD}$ standard deviation 
linolenic FA heritability estimate obtained in this study was similar to that found by some authors (0.13) [13] and lower than that reported by other studies (0.58) [34]. However, higher estimates have been reported for linolenic acid in other studies (0.21) [35], and also for palmitoleic acid (0.15) [13] and (0.49) [16]. Higher heritability estimates were reported for linoleic FA, 0.34 and 0.58 , respectively, in the intramuscular fat of Japanese Black cattle, suggesting that genetic influence on linoleic acid varies among breeds [34, 36]. Lower and similar heritability was estimated for myristic (0.18) and palmitic (0.21) FAs [26], respectively, while studies with Nellore estimated low heritability for these FAs, ranging from 0.08 to 0.17 [13]. However, studies [37] reported high estimates for the myristoleic FA (0.51) and [34] also found high estimates for myristic (0.70), palmitic (0.65), myristoleic $(0.60)$ and linoleic $(0: 58)$. Other authors also estimated low heritability estimates for the stearic [26, 37], CLA cis-9 trans-11 [13, 37] and arachidonic [13] FAs.

The heritability estimates for the sum of omega-3 series fatty acids, the n-6:n-3 ratio, and the sum of saturated and polyunsaturated fatty acids and their ratios were low $(<0.12)$. However, moderate heritability estimates were obtained for the sum of monounsaturated fatty acids and the sum of n- 6 and n-9 fatty acids. Studies estimated low heritability estimates for SFA and MUFA and moderate values for $n-3$ and $n-6$ [13, 37]. Low to moderate heritability estimates for PUFA (0.05 to 0.12 ), MUFA (0.06 to 0.20 ) and SFA (0.07 to 0.30 ) have been reported [26, 37, 38]. Nevertheless, other studies reported higher heritability estimates for these groups of fatty acids, 0.47 for PUFA, 0.35 to 0.66 for SFA and 0.35 to 0.68 for MUFA in Japanese Black cattle $[31,36]$. Recently, authors also estimated high heritability for SFA (0.54) and MUFA (0.54) and, therefore, concluded that there is sufficient genetic variation in the fatty acid profile of cattle subcutaneous fat to respond to selection [24]. The results of this study suggest that it is possible to change the lipids composition of intramuscular fat of Nellore meat through selection. This information is important for breeding programs of zebu breeds that aim at improving the beef fatty acid composition.

\section{GWAS and genomic regions}

The windows of 10 continuous SNPs that accounted for more than $1 \%$ of the genetic variance were used to search for putative candidate genes (PCG), which are represented in Tables 3, 4, 5 and 6. The results indicated a total of 115 different windows that explained more than $1 \%$ of the genetic variance for the 22 fatty acids studied.

In GWAS studies of intramuscular fat and fat deposition in meat of Nellore cattle, using the same marker density as in this study, the authors found 33genomic regions (windows with $1 \mathrm{Mb}$ SNPs) associated with the
Table 3 Genomic regions associated with the saturated fatty acids profile in intramuscular fat of the Longissimus thoracis muscle of Nellore

\begin{tabular}{|c|c|c|c|}
\hline Traits & QTL window & $\begin{array}{l}\text { \% Variance explained } \\
\text { SNP window }{ }^{a}\end{array}$ & $\mathrm{PCG}^{\mathrm{b}}$ \\
\hline \multirow[t]{4}{*}{ Total of SFA } & 1:113607033-113638343 & 1.29 & $-c$ \\
\hline & $4: 8338571-8365876$ & 6.64 & CDK14 \\
\hline & 5:115737350-115767786 & 2.59 & - \\
\hline & 23:51299188-51326222 & 3.71 & GMDS \\
\hline \multirow[t]{3}{*}{$\mathrm{C} 12: 0$} & 7:10826539-10852759 & 1.25 & - \\
\hline & 16:20584009-20601201 & 1.46 & ESRRG \\
\hline & 29:35323539-35335022 & 1.02 & - \\
\hline \multirow[t]{11}{*}{ C14:0 } & 1:71431023-71499402 & 2.52 & $\begin{array}{l}\text { SLC51A } \\
\text { PCYT1A } \\
\text { TCTEX1D2 }\end{array}$ \\
\hline & 1:109079423-112985104 & 1.43 & $\mathrm{PLCH} 1$ \\
\hline & 2:12006597-12035487 & 2.84 & - \\
\hline & 2:95199347-95226934 & 2.84 & ADAM23 \\
\hline & 2:108339996-108355638 & 3.93 & - \\
\hline & 8:4017767-4040618 & 1.61 & GALNTL6 \\
\hline & 9:5964257-5996599 & 1.34 & - \\
\hline & 9:75828407-75861439 & 1.34 & PEX7 \\
\hline & 12:1848851-1867387 & 1.23 & - \\
\hline & 17:33139235-33161695 & 1.38 & - \\
\hline & 29:14239868-14284421 & 1.25 & - \\
\hline \multirow[t]{8}{*}{ C16:0 } & $1: 71431023-71499402$ & 2.48 & $\begin{array}{l}\text { SLC51A } \\
\text { PCYT1A } \\
\text { TCTEX1D2 }\end{array}$ \\
\hline & 2:12009907-12039794 & 1.95 & - \\
\hline & 3:6449321-7462185 & 1.63 & $\begin{array}{l}\text { UAP } \\
\text { UHMK1 } \\
\text { HSD17B7 }\end{array}$ \\
\hline & 4:27962298-27989717 & 1.76 & - \\
\hline & 8: 4017767-4040618 & 2.47 & GALNTL6 \\
\hline & 9:7517866-7545663 & 1.73 & $\mathrm{BAI} 3$ \\
\hline & 12:21267027-22190566 & 2.90 & $\begin{array}{l}\text { ATP7B } \\
\text { DHRS12 }\end{array}$ \\
\hline & 20:1657499-1668052 & 1.80 & $\begin{array}{l}\text { FAM196B } \\
\text { DOCK2 }\end{array}$ \\
\hline \multirow[t]{5}{*}{ C18:0 } & 1:96012245-96039235 & 6.14 & FNDC3B \\
\hline & 2:125065946-125101312 & 1.45 & EPB41 \\
\hline & 3:115395556-115435819 & 8.33 & - \\
\hline & 8:100281732-100312597 & 3.90 & $\begin{array}{l}\text { TMEM245 } \\
\text { MIR32 }\end{array}$ \\
\hline & $17: 66287675-66303849$ & 1.45 & SVOP \\
\hline
\end{tabular}

Window that consists of continuous 10 SNPs

${ }^{\mathrm{b}}$ Positional/putative candidate gene

${ }^{c}$ No PCG associated with the trait

traits, deposition of intramuscular fat and meat fatty acid profile [13]. Similarly, other GWAS for Angus cattle, using a $54 \mathrm{~K}$ genotyping panel, found fifty-seven 
Table 4 Genomic regions associated with the monounsaturated fatty acids profile in the Longissimus thoracis of Nellore

\begin{tabular}{|c|c|c|c|}
\hline Trait & QTL window & $\begin{array}{l}\% \text { Variance explained } \\
\text { SNP window }\end{array}$ & $P C G^{b}$ \\
\hline \multirow[t]{5}{*}{ Total MUFA } & 4:31045067-31056443 & 1.27 & RAPGEF5 \\
\hline & 4:10646197-10655217 & 1.10 & $\begin{array}{l}\text { CALCR } \\
\text { MIR653 } \\
\text { MIR489 }\end{array}$ \\
\hline & 15:23027848-23042930 & 1.77 & $-c$ \\
\hline & 15:77580057-77608737 & 1.67 & CKAP5 \\
\hline & 17:19998159-20045296 & 1.43 & - \\
\hline \multirow[t]{3}{*}{ C14:1 } & 6:20782674-20793003 & 1.75 & ARHGEF38 \\
\hline & 3: 93656044-93678760 & 2.12 & SLC1A7 \\
\hline & 3: 106397884-106406683 & 1.64 & COL9A2 \\
\hline \multirow[t]{8}{*}{ C16:1 } & 5: 112777768-112833555 & 1.73 & MIR1281 \\
\hline & 5: $114505769-114536452$ & 1.22 & TTLL1 \\
\hline & 6: 88311624-88350890 & 1.79 & SLC4A4 \\
\hline & 12: 1698087-1733249 & 3.27 & TDRD3 \\
\hline & 14: 45588151-45625166 & 1.12 & - \\
\hline & 18: 1131250-1147435 & 1.35 & - \\
\hline & 22:22372870-22388066 & 1.08 & - \\
\hline & 28: $34505791-34523077$ & 1.04 & - \\
\hline \multirow[t]{7}{*}{ C18:1 cis-9 } & 3:6449321-6472465 & 1.29 & \\
\hline & $3: 60472950-60520103$ & 1.28 & \\
\hline & 4:2070739-2116544 & 1.12 & - \\
\hline & 7:85322486-85362698 & 1.11 & XRCC4 \\
\hline & 8:101007779-101024030 & 1.40 & PALM2 \\
\hline & 12:21265917-21282993 & 2.15 & $\begin{array}{l}\text { WDFY2 } \\
\text { DHRS12 }\end{array}$ \\
\hline & 23:44473841-44501022 & 10.59 & ADTRP \\
\hline \multirow[t]{6}{*}{ C18:1 trans-9 } & 4:8337794-8361230 & 12.00 & CDK14 \\
\hline & 8:68605036-68625678 & 1.29 & - \\
\hline & 9:78101823-78132552 & 1.87 & - \\
\hline & 12:61362119-61385432 & 1.12 & - \\
\hline & 18:56273509-56313047 & 1.45 & $\begin{array}{l}\text { CD37 } \\
\text { TEAD2 } \\
\text { DKKL1 } \\
\text { CCDC155 }\end{array}$ \\
\hline & 24:56810309-56821447 & 1.36 & WDR7 \\
\hline \multirow[t]{8}{*}{ C18:1 trans-11 } & 2: 59116358-59143632 & 1.78 & - \\
\hline & 4: 55957454-55984897 & 1.23 & - \\
\hline & 5: $99332464-99343514$ & 1.06 & YBX3 \\
\hline & 6: 1976981-2001221 & 1.30 & MARCH1 \\
\hline & 10: 39459983-39493584 & 2.34 & - \\
\hline & 10: $88628112-88637230$ & 1.26 & ESRRB \\
\hline & 14: 84372868-84383110 & 1.33 & SNTB1 \\
\hline & 26: 46130255-46142795 & 3.16 & ADAM12 \\
\hline
\end{tabular}

${ }^{a}$ Window that consists of continuous 10 SNPs

${ }^{\text {b Positional/putative candidate gene }}$

${ }^{c}$ No PCG associated with the trait genomic regions associated with the fatty acids profile trait in meat [16]. For any fatty acid, non-overlapping regions were found with the results obtained by [13, 14, 16], who also performed GWAS for beef FA profile in several breeds. Even though no overlapping regions were found for the same fatty acids, regions in the same chromosome were found, but at the longer distances $(>1 \mathrm{Mb})$. This inconsistent between our results and previous studies could be due the differences between studied populations (breed and environment), distribution of linkage disequilibrium among the causal mutations and genetic markers, model applied to perform the GWAS, genetic marker density. In addition, physiological and metabolic factors involved in those populations might help to explain the differences observed by researchers. In this sense, it is important to highlight that the expression of FA profile in beef is probably influenced by many loci of small effect. Thus, it is expected that each PCG contribute differently for the additive genetic variance of each FA in different populations, environments and management conditions.

\section{Saturated fatty acids}

A total of 31 genomic regions that explain more than $1 \%$ of genotypic were found for total saturated fatty acids, $\mathrm{C} 12: 0, \mathrm{C} 14: 0, \mathrm{C} 16: 0$ and $\mathrm{C} 18: 0$. These regions are distributed on chromosomes BTA1, BTA2, BTA3, BTA4, BTA5, BTA7, BТА8, ВТА9, ВТА12, ВТА16, BTA17, ВТА20, BTA24, and BTA29 (Table 3 and Additional file 1).

The regions identified on BTA1 and BTA5 chromosomes associated with the total saturated fatty acids had no PCG. BTA4 at $83 \mathrm{Mb}$ had a window that explained the highest percentage of additive genetic variance for the saturated fatty acids group (Fig. 1) and an associated candidate gene. The gene in this region is the CDK14 gene of the cyclin-dependent kinase family $(C D K)$. This gene is associated with production of kinase protein, enzymes that catalyze the phosphorylation of proteins by transferring one phosphoryl group of ATP and in exceptional cases, from GTP to threonine, serine (Ser/Thr specific kinase) or tyrosine residues (Tyr specific kinase) [39]. The region found on chromosome BTA23 (Fig. 1) houses the GMDS gene and acts on the metabolism of amino sugars and nucleotide sugars.

Three regions on different chromosomes were associated with lauric $(\mathrm{C} 12: 0)$ acid. The BTA7 at $10 \mathrm{MB}$ and BTA29 at $35 \mathrm{MB}$ with no associated candidate genes and BTA16 at $20 \mathrm{MB}$ associated with the ESRRG gene. Studies show that this gene is strongly correlated with the assembly and regulation of other adipogenic genes, and metabolism and transport of lipids [40, 41].

A total of 11 areas in seven different chromosomes (BTA1, BTA2, BTA8, BTA9, BTA12, BTA17, and BTA29) were associated with the myristic $(\mathrm{C} 14: 0)$ acid. Two 
Table 5 Genomic regions associated with the polyunsaturated fatty acids in the Longissimus thoracis muscle of Nellore

\begin{tabular}{|c|c|c|c|}
\hline Trait & QTL window & $\begin{array}{l}\text { \% Variance explained } \\
\text { SNP window }{ }^{\mathrm{a}}\end{array}$ & $P C G^{b}$ \\
\hline \multirow[t]{8}{*}{ C20:4 n-6 } & 3:3469461-3492275 & 2.15 & $-c$ \\
\hline & $5: 4417952-4432872$ & 3.06 & - \\
\hline & 9:84138533-84184280 & 4.95 & $\mathrm{FBXO30}$ \\
\hline & 15:27938668-27964533 & 1.17 & SIK3 \\
\hline & 16:61647491-61661042 & 2.34 & $\begin{array}{l}\text { RALGPS2 } \\
\text { ANGPTL1 }\end{array}$ \\
\hline & 19:61671067-62341372 & 5.01 & $\begin{array}{l}\text { ABCA5 } \\
\text { ABCA6 } \\
\text { ABCA10 } \\
\text { MAP2K6 } \\
\text { PRKAR1A }\end{array}$ \\
\hline & 21:70498936-70511360 & 1.72 & - \\
\hline & 23:25179729-25202537 & 4.20 & ELOVL5 \\
\hline \multirow[t]{6}{*}{$\begin{array}{l}\text { C18:2 cis9 } \\
\text { cis12 n6 }\end{array}$} & 1: $71431023-71499402$ & 4.92 & $\begin{array}{l}\text { SLC51A } \\
\text { PCYT1A } \\
\text { TCTEX1D2 }\end{array}$ \\
\hline & 8: 4017767- 4040618 & 2.06 & GALNTL6 \\
\hline & 11:82837386- 82851713 & 3.09 & DDX1 \\
\hline & 12: 1850108- 1876467 & 3.38 & - \\
\hline & 21:17398974- 17427182 & 4.04 & - \\
\hline & 23:44473841- 44501022 & 9.33 & ADTRP \\
\hline \multirow[t]{3}{*}{$\mathrm{C} 18: 3 \mathrm{n} 3$} & 4:111759995- 111777571 & 2.73 & CNTNAP2 \\
\hline & 12: 1721955-1759560 & 2.84 & TDRD3 \\
\hline & 12: 1848851-1867387 & 11.49 & - \\
\hline \multirow[t]{9}{*}{$C 22: 6 n-3$} & 1:35178519-35188850 & 1.20 & - \\
\hline & 3:24528861-24552342 & 1.46 & - \\
\hline & 7:92496213-92524656 & 1.20 & GPR98 \\
\hline & 8:108906430-108932062 & 5.10 & - \\
\hline & 12: 1848851-1867387 & 3.56 & - \\
\hline & 23:44473841-44501022 & 1.63 & ADTRP \\
\hline & 24:11304045-11346437 & 1.49 & - \\
\hline & 25:12681505-12706195 & 1.12 & - \\
\hline & 26:45184835-45225853 & 4.12 & - \\
\hline \multirow{7}{*}{$\begin{array}{l}\text { C20:3 n-6 } \\
\text { cis-8 cis-11 } \\
\text { cis-14 }\end{array}$} & 5: 5499399-5512486 & 1.31 & - \\
\hline & 8: 1640176-1659771 & 1.72 & - \\
\hline & 10:97347302-97359563 & 1.23 & - \\
\hline & 11:62497171-62519808 & 2.96 & PELI1 \\
\hline & 15: $7810022-7842535$ & 1.14 & - \\
\hline & 20: 1657499-1668052 & 1.39 & $\begin{array}{l}\text { FAM196B } \\
\text { DOCK2 }\end{array}$ \\
\hline & 25:12681505-12706195 & 1.80 & - \\
\hline \multirow[t]{2}{*}{ Total PUFA } & 14:21344791- 21376691 & 1.33 & - \\
\hline & 2:63074224-63103605 & 2.01 & TMEM163 \\
\hline
\end{tabular}

Table 5 Genomic regions associated with the polyunsaturated fatty acids in the Longissimus thoracis muscle of Nellore (Continued)

\begin{tabular}{lll}
\hline $10: 97347302-97359563$ & 1.52 & - \\
$12: 36843604-36886833$ & 6.24 & RNF17 \\
14:80616824- 80631460 & 1.97 & RALYL \\
21:17398974-17427182 & 1.23 & AGBL1 \\
23:44473841-44501022 & 6.79 & ADTRP \\
\hline
\end{tabular}

Window that consists of continuous 10 SNPs

${ }^{\mathrm{b}}$ Positional/putative candidate gene

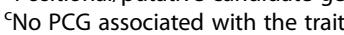

different regions have been identified for this acid. The first, BTA1 at $71 \mathrm{Mb}$ has three associated genes: SLC51A, $P C Y T 1 A$, and TCTEX1D2. The main candidate is $P C Y T 1 A$, which is a protein-coding gene controlling the phosphatidylcholine, a phospholipid emulsifier with detergent action that reduces surface tension, forming smaller fat particles as triglycerides [42] and has been related to fat percentage and body mass index in humans [43].

Table 6 Genomic regions associated with the omega-3 and omega- 6 fatty acids, and the omega-6/omega-3 ratio in the Longissimus thoracis muscle of Nellore

\begin{tabular}{|c|c|c|c|}
\hline Trait & QTL window & $\begin{array}{l}\text { \% Variance explained } \\
\text { SNP window }{ }^{\mathrm{a}}\end{array}$ & $P C G^{b}$ \\
\hline \multirow[t]{6}{*}{ Total n-3 } & $3: 7439426-7455843$ & 1.14 & NOS1AP \\
\hline & 7:92487944-92521811 & 1.45 & GPR98 \\
\hline & 8:88219918-88234648 & 9.99 & $-c$ \\
\hline & 12:1850108-1876467 & 3.53 & - \\
\hline & 21:17398974-17427182 & 1.13 & LOC100300175 \\
\hline & 25:12775670-12817779 & 1.22 & - \\
\hline \multirow[t]{6}{*}{ Total n-6 } & 2:63074224-63103605 & 1.68 & TMEM163 \\
\hline & 3:49887762-49898290 & 1.41 & BCAR3 \\
\hline & 10:97347302-97359563 & 1.69 & - \\
\hline & 12:36843604-36886833 & 5.61 & RNF17 \\
\hline & 14:80616824-80631460 & 1.86 & RALYL \\
\hline & 23:44473841-44501022 & 6.68 & ADTRP \\
\hline \multirow{9}{*}{$\begin{array}{l}\text { Ratio of } \\
n-6: n-3\end{array}$} & 1:60602819-60636700 & 1.11 & - \\
\hline & 2:131895441-131915476 & 1.69 & - \\
\hline & 3:53399171-53439878 & 1.39 & ZNF326 \\
\hline & 6:28611816-28631205 & 1.92 & - \\
\hline & 10:52660431-52708192 & 1.01 & POLR2M \\
\hline & 10:88145431-88173762 & 1.01 & TTLL5 \\
\hline & 16:46586463-46598618 & 1.78 & - \\
\hline & 16:63634797-63657084 & 1.61 & MR1 \\
\hline & 29:10816550-10828285 & 1.16 & LOC505383 \\
\hline
\end{tabular}

Window that consists of continuous 10 SNPs

${ }^{\mathrm{b}}$ Positional/putative candidate gene

${ }^{c}$ No PCG associated with the trait 


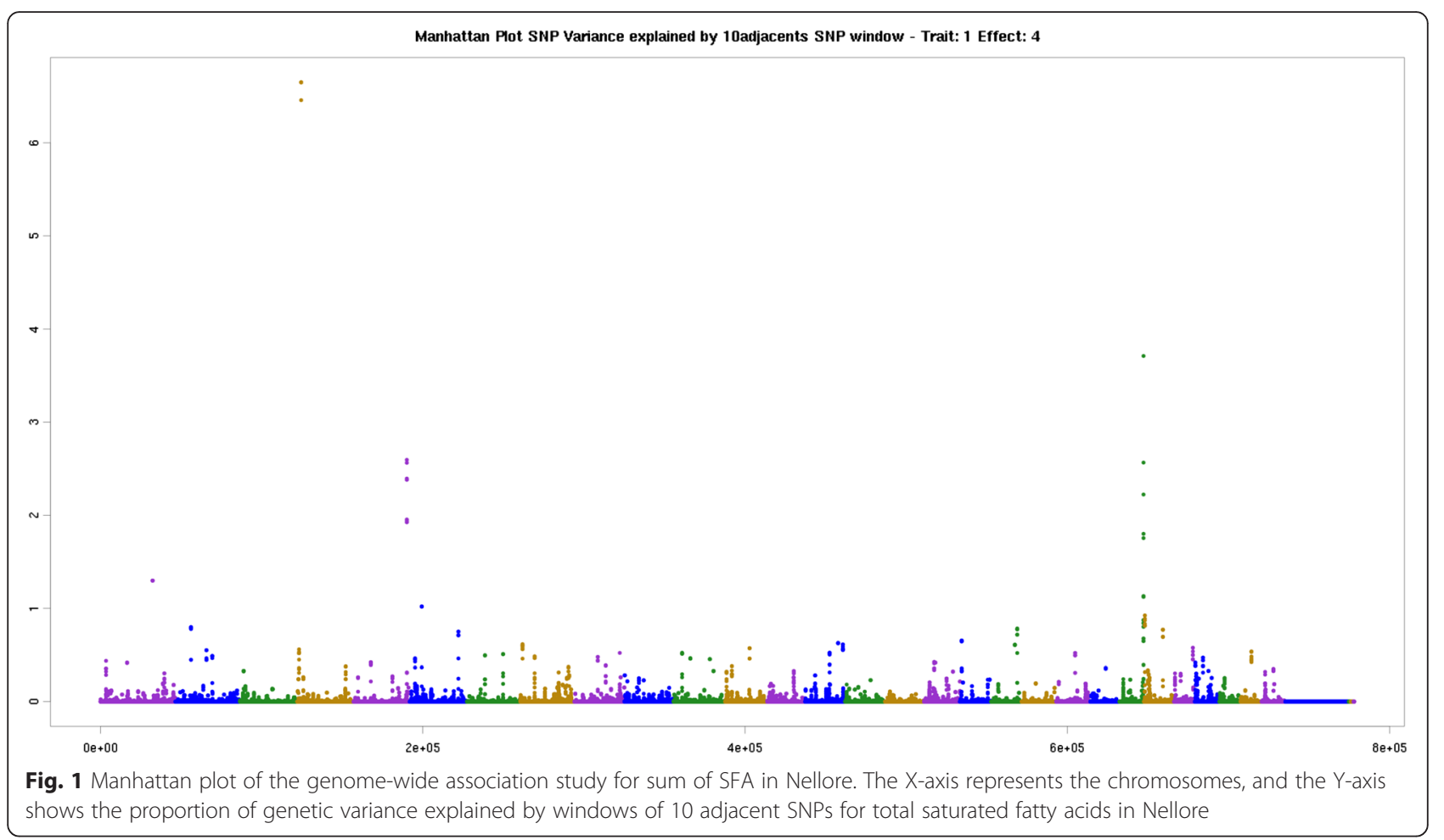

The second region was identified on BTA1 at $112 \mathrm{Mb}$ and associated with the PLCH1 gene. This gene is a protein-coding, member of the PLC-eta family of the phosphoinositide-specific phospholipase $\mathrm{C}(P L C)$ superfamily of enzymes that cleave phosphatidylinositol 4,5-bisphosphate $(\operatorname{PtdIns}(4,5) \mathrm{P} 2)$ to generate second messengers inositol 1,4,5-trisphosphate (IP3) and diacylglycerol (DAG). Phospholipases are a group of enzymes that hydrolyze phospholipids into fatty acids and other lipophilic molecules. The PLC enzyme is subdivided into beta, gamma, delta, epsilon, zeta, and eta subtypes, which catalyze the hydrolysis of phosphatidylinositol 4,5-bisphosphate (PIP2) into inositol 1,4,5-trisphosphate (IP3) and 1.2-diacilglicerol (DAG). Phospholipases are usually expressed and have diverse biological functions, including a role in inflammation [44]. On BTA2 at $95 \mathrm{Mb}$, a candidate gene was associated with the fatty acid C14:0, ADAM23, which, among other functions, was found to suppress adipogenesis in mice [45]. BTA8 at $4 \mathrm{Mb}$ had a candidate gene (GALNTL6) associated with C14:0. This gene catalyzes the initial reaction in the biosynthesis of oligosaccharides, transferring an $\mathrm{N}$-acetyl$\mathrm{D}$-galactosamine residue to a serine or threonine residue in the protein receptor [46]. The PEX7 gene was identified on BTA9 at $75 \mathrm{Mb}$. This gene encodes cytosolic receptor for the set of enzymes of peroxisomal matrix targeted to the organelle by the PTS2. Mutations in this gene cause disorders in peroxisome biogenesis, which are characterized by multiple modifications in the peroxisome function [47].
Eight regions on different chromosomes were identified for the palmitic (C16:0) acid, BTA1 at $71 \mathrm{Mb}$, BTA2 at $12 \mathrm{Mb}, \mathrm{BTA} 3$ at $6 \mathrm{Mb}, \mathrm{BTA} 4$ at $27 \mathrm{Mb}, \mathrm{BTA} 8$ at $4 \mathrm{Mb}, \mathrm{BTA} 9$ at $7 \mathrm{Mb}, \mathrm{BTA} 12$ at $21 \mathrm{Mb}$ and BTA20 at $1 \mathrm{Mb}$. The first region found (BTA1 at $71 \mathrm{Mb}$ ) was exactly the same QTL region found for the saturated fatty acid $C 14: 0$ and associated with the same genes (SLC51A, PCYT1A, and TCTEX1D2). The larger genomic region found for the group of saturated fatty acids is on BTA3 at $6 \mathrm{Mb}$ (Table 3). This region had only $1.63 \%$ of the additive genetic variance for the trait C16:0, in which three candidate genes were located: UAP1, UHMK1, and HSD17B7. The HSD17B7 encodes an enzyme with the same function of the 17-betahydroxysteroid dehydrogenase (EC 1.1.1.62) in sex steroid biosynthesis and 3-ketosteroid reductase (EC 1.1.1.270), and acts on the biosynthesis of cholesterol [48]. This gene is expressed in most lineages of fastgrowing broilers [49] and is found in the subcutaneous and omental adipose tissue in humans [50].

The region identified on BTA 8 at $4 \mathrm{Mb}$ for myristic (C14:0) acid, where the same GALNTL6 gene described above was located. The BAI3 gene identified on BTA9 at $7 \mathrm{Mb}$ is known to participate in the myoblast fusion; it is present in the extracellular matrix and plays a role in the adipose tissue formation [51]. The BTA12 at $21 \mathrm{Mb}$ QTL was associated with two PCGs: $A T P 7 B$ and $D H R S 12$. The ATP7B gene participates in the regulation 
of copper in the body. Mice with this non-functional gene present altered cholesterol and fatty acids synthesis [52]. The DHRS12 encodes a member of the dehydrogenase/reductase short-chain family. Members of this family are enzymes that metabolize many compounds, such as steroid hormones, prostaglandins, retinoids, lipids and xenobiotics [53] and a deletion of the region where the gene is associated with lipomas in humans [54]. BTA20 at $1 \mathrm{Mb}$ was associated with two PCG: FAM196B and DOCK2, the latter is involved in actin cytoskeleton remodeling through activation of RAC GTPase [55] and interacts with various lipids [56].

Five different regions were associated with stearic (C18:0) acid and only one, BTA3 at $115 \mathrm{Mb}$, was not identified with any PCG. The candidate gene FNDC3B was located on BTA1 at $96 \mathrm{Mb}$ while the EPB41 gene, on BTA2 at $125 \mathrm{Mb}$. Two PCGs were identified on BTA 8 at $100 \mathrm{Mb}$ : transmembrane protein 245 (TEMEM245) and microRNA 32 (MIR32). However, none of these genes has a described function in lipid metabolism.

\section{Monounsaturated fatty acids (MUFA)}

A total of 37 genomic regions, distributed over sixteen different chromosomes, account for more than $1 \%$ of the genetic variance for monounsaturated fatty acids, which relates to total monounsaturated fatty acids, C14:1, C16:1, C18:1 trans11, C18:1 cis9 and C18:1 trans9 (Table 4 and Additional file 1).

In the first region of BTA4 at $31 \mathrm{Mb}$, the RAPGEF5 gene was associated with total monounsaturated fatty acids. In the second region, all three genes were identified: CALCR, MIR653, and MIR489. The CALCR gene expression is associated with the production of various lipids in humans [57] and has SNPs associated with the production of milk fat and body condition in dairy cattle [58]. The BTA15 at $77 \mathrm{Mb}$ was associated with the CKAP5 gene. No PCG was identified on BTA17 at $19 \mathrm{Mb}$, and BTA15 at $23 \mathrm{Mb}$. The C16:1 FA was associated to ten different regions where six PCG were found in. For the first region, BTA3 at $93 \mathrm{Mb}$, the gene $S L C 1 \mathrm{~A}$ was identified. The family of this gene includes five high-affinity glutamate transporters, EAAC1, GLT-1, GLAST, EAAT4 and EAAT5 (SLC1A1, SLC1A2, SLC1A3, $S L C 1 A 6$, and $S L C 1 A 7$, respectively), also known as excitatory amino acid transporters (EAATs), which are sodium and potassium-dependent members of the solute carrier family 6 (SLC1) found widely distributed in the whole brain [59]. On BTA3 at $106 \mathrm{Mb}$ one PCG was identified, COL9A2, which is related to extracellular matrix structural constituent conferring tensile strength according to gene ontology (GO:0030020).

On BTA3, at $6 \mathrm{Mb}$ and $60 \mathrm{Mb}$, BTA4 at $2 \mathrm{Mb}$, BTA7 at $85 \mathrm{Mb}$ and BTA 8 at $101 \mathrm{Mb}$, BTA12 at $21 \mathrm{Mb}$ and BTA23 at 44 MB were associated with oleic acid (C18:1 cis 9). BTA7 at $85 \mathrm{Mb}$ was associated with the PCG, XRCC4. Studies shows that this gene functionally complements XR-1 Chinese hamster ovary cell mutant, which is impaired in DNA double-strand breaks produced by ionizing radiation and restriction enzymes [60]. On BTA8 at $101 \mathrm{Mb}$, the PCG PALM2 was identified. Two genes were identified on BTA12 at $21 \mathrm{Mb}$ : WDFY2 and DHRS12. On BTA23 at $44 \mathrm{Mb}$, the ADTRP. The genes DHRS12 and ADTRP were the same reported for $\mathrm{C} 16: 0$, thus are described above. The genomic region that explained most of the genetic variance of the unsaturated fatty acids group was located on BTA4 at $8 \mathrm{Mb}$, where the CDK14 gene was associated with the C18:1 trans-9 (elaidic acid) (Fig. 2). The same region was found for total saturated fatty acids (Table 3), where the CKD14 gene is associated with the same two traits described above. On BTA18 at $56 \mathrm{Mb}$, four genes associated with the above traits were identified: $C D 37, T E A D 2$, DKKL1 and CCDC155.

The vacenic fatty acid (C18:1 trans 11$)$ was associated with eight regions in seven different chromosomes. One of these regions, on BTA10 at $88 \mathrm{Mb}$, was the same associated with lauric (C12:0), thus the PCG ERSSB gene was described above.

\section{Polyunsaturated fatty acids (PUFA)}

Forty genomic regions explained more than $1 \%$ of the additive genetic variation for the polyunsaturated fatty acids group, as: C20:4 n-6, C18:2 cis-9 cis12 n-6, C18:3 n-3, C22:6 n-3 and C20:3 n-6 cis- 8 cis- 11 cis-14 (Table 5 and Additional file 1).

On BTA2 at $63 \mathrm{Mb}$, the TMEM163 gene was associated with the total PUFA. TMEM 163 variants were associated with decreased fasting plasma insulin and also with the homeostatic model assessment of insulin resistance, indicating plausible effect through impaired insulin secretion [61]. The fatty acid C20:4 n-6 was associated with eight different genomic regions (Table 5). On BTA9 at $84 \mathrm{Mb}$, the $F B X O 30$ gene was associated with arachidonic acid. BTA19 at $61 \mathrm{Mb}$ (the largest region found for the group of polyunsaturated fatty acids) had five associated genes: $A B C A 5, A B C A 6, A B C A 10, M A P 2 K 6$, and PRKAR1A. The genes of the ABC Group are associated with cholesterol metabolism and lipids homeostasis [62], as well as $A B C A 5, A B C A 6$ and $A B C A 10[63,64]$. The MAP2K6 gene was associated with backfat thickness, marbling score and carcass weight in Hanwoo cattle [65] and identified in two selection signatures in Galloway and Gelbvieh cattle [66]. The PRKAR1A is involved in the regulation of lipid and glucose metabolism and is a component of the signal transduction mechanism of certain GPCRs (G-protein coupled receptor) [67]. Mutations in this gene have been associated with obesity phenotypes in humans [68]. 




On BTA23 at $25 \mathrm{Mb}$, the ELOVL fatty acid elongase 5 (ELOVL5) gene was associated with the fatty acid C20:4 n6 . This gene plays an important role in the elongation of saturated and monounsaturated fatty acids up to 24 carbons (GO:0009922), condensing enzymes that catalyze the synthesis of monounsaturated and polyunsaturated fatty acids of very long chains, specifically the current polyunsaturated acyl-CoA with higher activity C18:3(n-6) acylCoA [69]. In mammals, seven enzymes have been identified in the ELOVL family (ELOVL1-7). Each ELOVL enzyme has a distinct distribution in different tissues, and different enzymes exhibit different preferences for the fatty acid substrate. The ELOVL5 and ELOVL6 genes are involved in the production/synthesis of palmitic (C16:0), palmitoleic (C16:1), stearic $(\mathrm{C} 18: 0)$ and oleic (C18:1) fatty acids, important beef fatty acids. Therefore, the role of ELOVL5 and ELOVL6 genes in the synthesis of these fatty acids is of great importance in beef breeding programs [70, 71].

The genomic regions of BTA 1 at $71 \mathrm{Mb}, \mathrm{BTA} 8$ at $4 \mathrm{Mb}, \mathrm{BTA} 11$ at $82 \mathrm{Mb}, \mathrm{BTA} 12$ at $1 \mathrm{Mb}, \mathrm{BTA} 21$ at 17 $\mathrm{BM}$ and BTA23 at $44 \mathrm{Mb}$ were associated with the linoleic (C18:2 cis-9 cis-12; n-6) acid. The two regions, BTA1 at $71 \mathrm{Mb}$ and BTA 8 at $4 \mathrm{Mb}$ were similar to those observed for the saturated fatty acids C14:0 and C16:0, where the SLC51A, PCYT1A, TCTEX1D, and GALNTL6 genes have been previously described. The BTA23 at $44 \mathrm{Mb}$ position had a candidate gene associated and explaining a important proportion of the additive genetic variance of the polyunsaturated fatty acids group (Fig. 3). This same region had the ADTRP gene associated with total polyunsaturated fatty acids. The BTA11 at $82 \mathrm{MB}$ was associated with C18:2 cis-9 cis-12 n-6, (gene: AspGlu-Ala-Asp) box helicase 1 (DDX1), which acts as a RNA helicase dependent of ATP, able to relax both RNA-RNA and DNA-RNA duplexes [72].

BTA4 at $111 \mathrm{Mb}$ and BTA12 at $1 \mathrm{Mb}$ were associated with the linolenic (C18:3 n-3.) BTA4 at $111 \mathrm{Mb}$ was associated with the CNTNAP2 gene, which implies dietinduced obesity [73]. The gene tudor domain containing 3 (TDRD3) was identified on BTA12 at $1 \mathrm{Mb}$ [74].

Nine QTL regions were associated with C22:6 n-3 FA, but PCGs were found in only two of these regions: BTA7 at $92 \mathrm{Mb}$ and BTA23 at $44 \mathrm{Mb}$. BTA7 at $92 \mathrm{Mb}$ was associated with the GPR98 gene. This gene encodes a member of the receptors superfamily coupled to the $G$ protein. This encoded protein contains a seventransmembrane receptor domain bound to calcium. It is expressed in the central nervous system [75] and associated with the body condition score in humans [60]. BTA23 at $44 \mathrm{Mb}$ was also associated with the fatty acid C18:2 cis-9 cis-12 n-6 and, therefore, PCG ADTRP has been described above.

The fatty acid C20:3 n- 6 cis- 8 cis- 11 cis-14 was associated with seven regions in seven different chromosomes, but PCGs were identified in only two regions: BTA11 at $62 \mathrm{MB}$ and BTA20 at $1 \mathrm{Mb}$. The PCG Pellino E3 ubiquitin protein ligase 1 (PELI1) was identified on BTA11 at $62 \mathrm{Mb}$. BTA20 


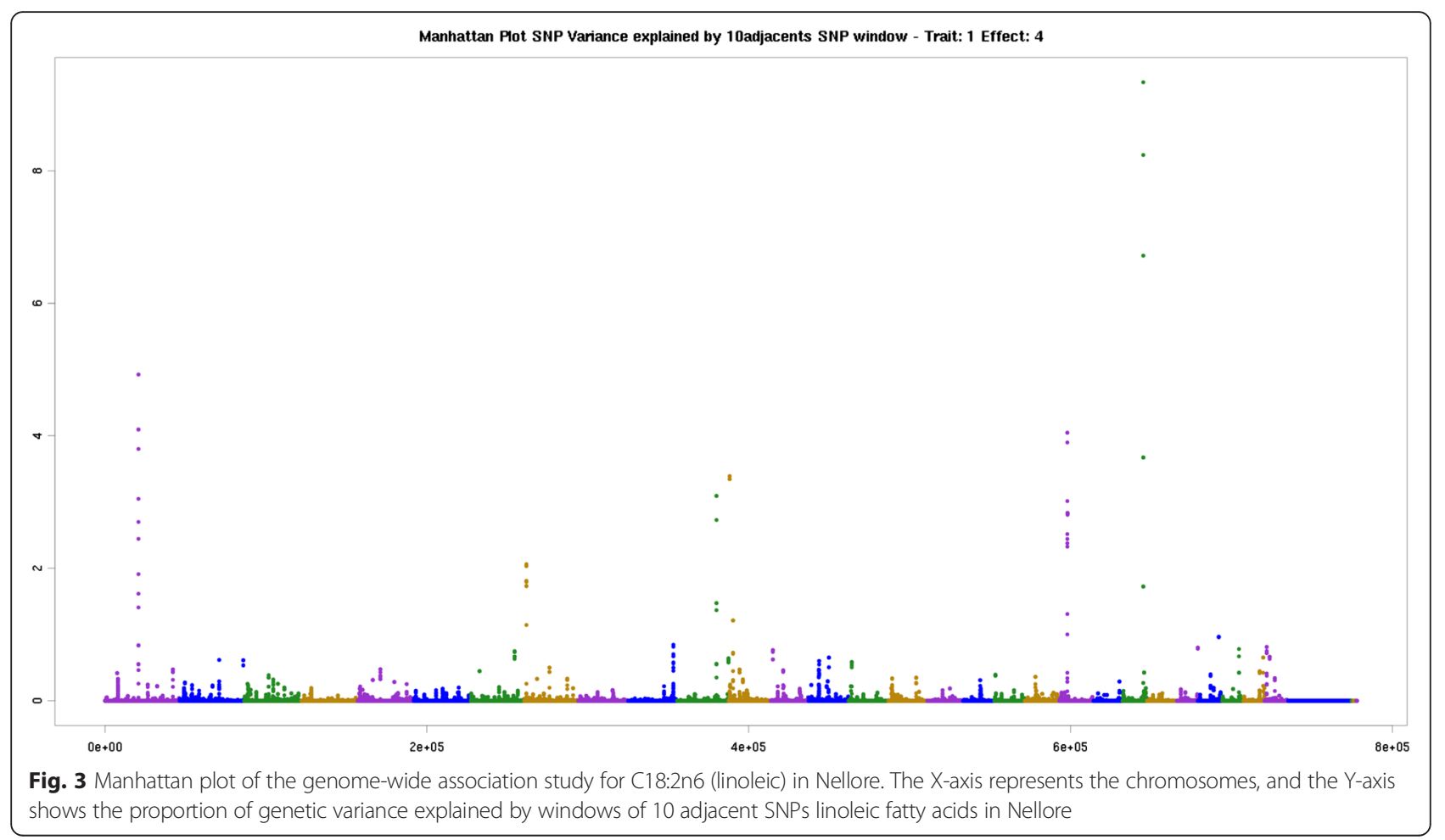

at $1 \mathrm{Mb}$ had two PCGs identified: family with sequence similarity 196, member B (FAM196BI) and dedicator of cytokinesis 2 (DOCK2). DOCK2 is involved in cytoskeletal rearrangements necessary for lymphocyte migration in response to chemokines. This PGC activates RAC1 and $R A C 2$, but not the $C D C 42$, because it acts as a guanine exchange factor (GEF) nucleotide that changes the GDP to free GTP [55].

\section{Omega 3 and 6 fatty acids}

A total 21 genomic regions accounted for more than $1 \%$ of the genetic variance for $n-3$ and $n-6$ fatty acids, and the n-6:n-3 ratio (Table 6 and Additional file 1).

On BTA3 at $7 \mathrm{Mb}$, BTA7 at $92 \mathrm{Mb}, \mathrm{BTA} 8$ at $88 \mathrm{Mb}$, BTA12 at $1 \mathrm{Mb}$, BTA21 at $17 \mathrm{Mb}$, and BTA25 at $12 \mathrm{Mb}$ were associated with total n-3 fatty acids. On the other hand, no PCGs were identified on BTA 8 at $88 \mathrm{Mb}$, BTA12 at $1 \mathrm{Mb}$, and BTA25 at $12 \mathrm{Mb}$. Moreover, BTA3 at $\mathrm{Mb} 7 \mathrm{Mb}$ and BTA7 at 92 were also associated with the C18:1 cis-9 and C22:6 n-3 fatty acids (FA) and, therefore, with the NOS1AP and GPR98 genes described above, respectively.

On BTA2 at $63 \mathrm{Mb}, \mathrm{BTA} 3$ at $49 \mathrm{Mb}, \mathrm{BTA} 10$ at $97 \mathrm{Mb}$, BTA12 at $36 \mathrm{Mb}$, BTA14 at $80 \mathrm{Mb}$ and BTA23 at $44 \mathrm{Mb}$ were associated with total n- 6 fatty acids. The BTA2 at $63 \mathrm{Mb}$ harbors the gene transmembrane protein 163 (TMEM163). This same region has also been associated with total polyunsaturated fatty acids (PUFA). The BTA3 at $49 \mathrm{Mb}$ was the largest region associated with the omega fatty acids group, where the BCAR3 gene is found. This gene has been linked to breast cancer in humans [76]. BTA12 at $36 \mathrm{Mb}, \mathrm{BTA} 14$ at $80 \mathrm{Mb}$ and BTA23 at $44 \mathrm{Mb}$ have been associated previously with other long-chain fatty acids, whereas the latter region explained the greatest proportion of variance (Fig. 4). BTA12 at $36 \mathrm{Mb}$ and BTA14 at $80 \mathrm{Mb}$ were also associated with total polyunsaturated fatty acids and the genes already described. BTA23 at $44 \mathrm{Mb}$ was also associated with the polyunsaturated FAs: C18:2 cis-9 cis-12 n-6, C22:6 n-3 and total PUFA.

The single step method method allows to combine the information of genotyped and non-genotyped animals in the genetic evaluation process, thus expanding the scope and identification of potential regions associated with loci responsible for variations in the studied traits [77]. In this sense, some authors [78] compared different GWAS methodologies and reported that the single step method method partitions the genetic variance for a particular region among all SNPs markers. On the other hand BayesB or BayesCpi methods, for example, penalizes the zero regions and tends to overestimate the genetic variability explained for each of the identified regions. There is some controversy regarding the capacity or ability of different methods to identify genomic regions associated with the phenotype [20-22]. Therefore, caution should be applied when interpreting results from different populations, using various methods because the identified associations depend on the strength 


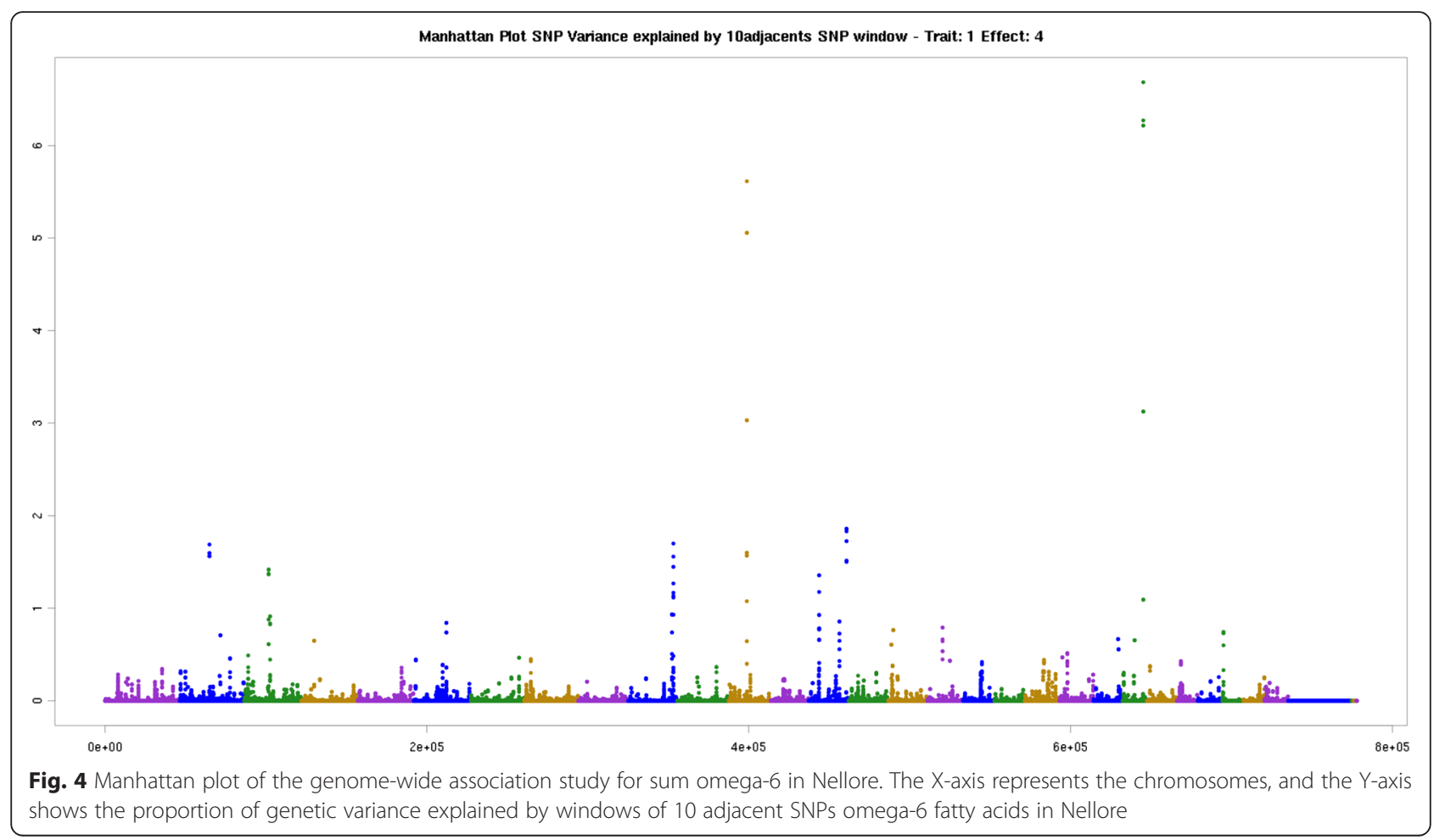

or magnitude of the association, methodology, and implementation details.

In this study, we found several nearby areas of major QTL associated with groups of saturated, monounsaturated, and polyunsaturated fatty acids, in Nellore meat. These regions harbor interesting PCG, which are involved in lipid metabolism, as a constituent of cell membranes, receptors for reproductive hormones, biosynthesis and hydrolysis of phospholipids and membrane constituents, synthesis of protein kinases, transport and use of fatty acids and cholesterol, energy metabolism, elongation factors and synthesis of long-chain fatty acids in different species. Among the many genes identified, the ELOVL5 gene located on chromosome BTA23 at $25 \mathrm{Mb}$ and associated with the C20:4 n-6 (arachidonic acid) is highlighted. The genes responsible for the elongation of very-long-chain fatty acid $(E L O V L)$ encode enzymes that play an important role in the elongation of long-chain fatty acids. The fatty acid synthesis involves a number of enzymes, such as fatty acid synthase $(F A S N)$, which is located on chromosome BTA19 between 51.384 .922 and 51.403 .614 bp, while its variations have been related to fatty acid composition of Angus beef [79]. In mammals, FASN synthesizes the fatty acids that contain up to 16 carbon atoms, and the genes of the ELOVLs group produce long-chain fatty acids with 18 carbon atoms or more $[80,81]$.

The results of the present study pointed out some PCG that were found associated to several FA of different saturation state: the CDK14 gene was associated with C18:1 trans-9 and SFA; the TMEM163 gene related to $\mathrm{n}-6$ fatty acids and PUFA; and the SLC51A, PCYT1A, TCTEX1D, and GALNTL6 genes that influence the linoleic acid and also some individual saturated fatty acids, like the C14:0 and C16:0. These results could be due to pleitropic effects, where the expression of differents FA could influenced by the same gene which acts in a coordinate manner to contribute to the synthesis of beef FA. Similar findings were reported by [16], where both genes, FASN and THRSP, exhibited pleiotropic effect for the most studided FA in Angus cattle. Genes involved in muscle lipid composition of 15 european Bos taurus breeds were studied by [82], which reported pleiotropic effects for genes like CRI1, DGAT1, FOXO1, MMP1, $S O C 2$ and $N E B$, affecting several beef FA.

The large number of genomic regions associated with the fatty acid profile found in this study should help to understand the genetic and metabolic mechanisms that determine the fatty acids profile of intramuscular fat, especially in zebu. According to the results of this study, the meat fatty acid profile of Zebu is probably controlled by several QTL of small effect and, therefore, the identification of relevant genes or large effect seems to be difficult, since for most fatty acids, the contribution of each region or window for the additive genetic variation was small. Therefore, strategies such as genomic selection using or considering the variability among markers at the same time would be more appropriate to improve the fatty acid profile of the bovine meat. The database 
used in the study is broad since it contains animals that participate in beef cattle breeding programs, and breeders that are sold and used in various regions of the country. Therefore, the results should contribute to the selection and improvement of the meat quality from zebu raised in tropical conditions.

\section{Conclusion}

Several genomic regions associated with QTL related to lipid metabolism and fatty acid composition were identified. The identification of such regions and the respective candidate genes associated with lipid metabolism and energy transport hormones such as, for example, ELOVL5, ESSRG, PCYT1A and genes of the $A B C$ group ( $A B C 5, A B C 6$ and $A B C 10$ ), should contribute to improve the genetic knowledge regarding the fatty acids profile of Nellore (Bos indicus) and help to improve the selection of such traits to favor human health. In addition, these regions can be used in future fine mapping studies, whose primary function is to search for informative causative mutations. These polymorphisms can be inserted into customized low-density chips that assist a more cost-effective genetic evaluation.

\section{Methods}

\section{Local, animals and management}

This study was approved by ethics committee of the Faculty of Agrarian Sciences and Veterinary, Sao Paulo State University (UNESP).

The database contains animal data from eight farms located in the Southeast, Northeast and Midwest of Brazil, which are part of breeding cattle programs. Genotypes $(n=1616)$ and phenotypes $(n=963)$ of Nellore bulls, with average initial age of 24 months, were used. The animals belonged to eight different farms located in the Southeast, Northeast and Midwest regions of Brazil, which participate in three beef cattle breeding programs (NeloreQualitas, Paint and DeltaGen). In these breeding programs animals are selected based on growth, finishing and sexual precocity traits.

Breeding seasons are adopted at different periods on these farms. Therefore calving seasons concentrate from August to October in some farms and from November to January in others, and weaning was performed at seven months of age. The animals were raised on grazing conditions using Brachiaria sp. and Panicum $s p$ forages, and free access to mineral salt, at density varying from 1.2 to 1.6 animal unit/hectare (AU/ha. After yearling, the breeding animals were selected and the rest remained in feedlot. During feedlot, the forage: concentrate ratio ranged from 50:50 to 70:30, depending on the farm. In general, whole-plant corn or sorghum silage was used as high quality forage. Grains of corn and/or sorghum, and soybeans, soybean meal, or sunflower seeds were used as protein concentrate. The criteria used by farmers for slaughtering was weight (500-550 kg). After stored for $48 \mathrm{~h}$ at $0-2{ }^{\circ} \mathrm{C}$, meat samples were removed from the Longissimus thoracis muscle, between the 12 and 13th ribs from each animal, placed in plastic bags and stored at $-80{ }^{\circ} \mathrm{C}$ until further analysis to determine the fatty acid profile. The percentage of lipids in the Longissimus thoracis muscle (IMF) was obtained using the method proposed by [83].

\section{Determination of the fatty acid profile}

The total lipid concentration was quantified at the Animal Product Technology Laboratory in the Technology Department of FCAV/Unesp using the Bligh and Dyer [84] method. The meat fatty acids were extracted using the method of Folch et al. [83] and the methyl esters were formed according to Kramer et al. [85]. The fatty acid profile was determined at the Meat Science Laboratory (LCC) in the Department of Animal Nutrition and Production at FMVZ/USP, using the extraction method by Folch et al. [83]. Muscle samples ( 100 g) were collected and ground to determine the fatty acid profile. The lipids were extracted by homogenizing the sample with a chloroform and methanol (2:1) solution. $\mathrm{NaCl}$ at $1.5 \%$ was added to isolate the lipids.

The separated fat was methylated, and the methyl esters were formed according to Kramer et al. [85]. The fatty acids were quantified by gas chromatography (GC2010 Plus - Shimadzu AOC 20i auto-injector) with a $100 \mathrm{~m} \mathrm{SP}-2560$ capillary column $(0.25 \mathrm{~mm}$ in diameter with $0.02 \mathrm{~mm}$ thickness, Supelco, Bellefonte, PA). The initiating temperature of $70{ }^{\circ} \mathrm{C}$ was increased gradually up to $175{ }^{\circ} \mathrm{C}\left(13{ }^{\circ} \mathrm{C} / \mathrm{min}\right)$, held for $27 \mathrm{~min}$, and increased further up to $215{ }^{\circ} \mathrm{C}\left(4{ }^{\circ} \mathrm{C} / \mathrm{min}\right)$ and held for $31 \mathrm{~min}$. Hydrogen (H2) was the carrier gas, with $40 \mathrm{~cm} 3 / \mathrm{s}$. Fatty acids were identified by comparing the retention time of methyl esters of the samples with the standards C4-C24 (F.A.M.E mix Sigma ${ }^{\circ}$ ), vaccenic acid C18:1 trans-11 (V038-1G, Sigma ${ }^{\circ}$ C18:2 trans-10 cis-12 (UC-61 M $100 \mathrm{mg}$ ), CLA e C18:2 cis-9, trans-11 (UC- $60 \mathrm{M}$ $100 \mathrm{mg}),\left(\right.$ Sigma $\left.^{\circ}\right)$ and tricosanoic acid $\left(\right.$ Sigma $\left.^{\circ}\right)$. Fatty acids were quantified by normalizing the area under the curve of methyl esters using the GS solution 2.42 software. Fatty acids were expressed as a percentage of the total fatty acid methyl ester. The fatty acid profile in meat was performed at the Meat Science Laboratory (LCC) in the Department of Animal Nutrition and Production at FMVZ/USP.

The following individual fatty acids were selected: lauric (C12:0), myristic (C14:0), palmitic (C16:0), stearic (C18:0), myristoleic (C14:1), palmitoleic (16:1), oleic (C18:1 cis-9), elaidic (C18:1 trans9), CLA-cis (C18:2c9t11), CLA-trans (C18:2 trans10 cis 12), vaccenic (C18:1 trans11), linoleic 
(C18:2 cis9Cis12n6), docosahexaenoic (DHA) (C22:6 n3), and eicosatrienoic FA (C20:3 n6 cis-8,11,14). These FA were chosen due to their importance to human health and their high content in animals from confinement, such as the oleic acid. The sum of saturated $(\mathrm{C} 10: 0+\mathrm{C} 11: 0+$ $\mathrm{C} 12: 0+\mathrm{C} 13: 0+\mathrm{C} 14: 0+\mathrm{C} 15: 0+\mathrm{C} 16: 0+\mathrm{C} 17: 0+\mathrm{C} 18: 0+$ $\mathrm{C} 21: 0+\mathrm{C} 24: 0)$, monounsaturated $(\mathrm{C} 16: 1+\mathrm{C} 17: 1$ c10 + C18:1 t11 + C15:1 c10 + C20:1 c11 + C24:1 + C22:1 $\mathrm{n} 9+\mathrm{C} 18: 1 \mathrm{n} 9 \mathrm{c}+\mathrm{C} 14: 1+\mathrm{C} 18: 1 \quad \mathrm{n} 9 \mathrm{t}), \quad$ polyunsaturated $(\mathrm{C} 18: 2 \mathrm{n} 6+\mathrm{C} 18: 3 \mathrm{n} 3+\mathrm{C} 18: 3 \mathrm{n} 6+\mathrm{C} 20: 3$ n3 cis-11, 14, 17 + C20:3 n6 cis-8, 11, 14 + C20:4 n6 + C20:5 n3 + C22:6 n3), omega 6 (C18:3 n6 + C20:3 n6 c8, c11, c14+C18:2 $\mathrm{n} 6+\mathrm{C} 20: 4 \mathrm{n} 6)$ and omega 3 (C18:3 n3 + C20:3 n3 c11, c14, c17 + C22:6 n3 + C20:5 n3) were calculated. The polyunsaturated/saturated fatty acids and $n-6 / n-3$ ratios were also calculated.

\section{Genotyping of animals}

A total of 1616 animals were genotyped using 777,962 SNPs of the Bovine SNP BeadChip (High-Density Bovine BeadChip). The quality control of the SNPs markers consisted of excluding those with unknown genomic position, located on sex chromosomes; monomorphic and markers with minor allele frequency (MAF) less than 0.05; call rate less than $90 \%$, and markers with excess heterozygosity. Samples with a call rate less than $90 \%$ were also excluded. After quality control, 470,007 SNPs from 1,556 animal samples were left.

\section{Analysis of the genomic association}

To perform the GWAS analyses the single-step GBLUP (ssGBLUP) method was applied. The ssGBLUP model is a modification of BLUP with numerator relationship matrix $\mathrm{A}^{-1}$ matrix replaced by $\mathrm{H}^{-1}$ [86]:

$$
H^{-1}=A^{-1}+\left[\begin{array}{cc}
0 & 0 \\
0 & G^{-1}-A_{22}^{-1}
\end{array}\right]
$$

Where, $A_{22}$ is a numerator relationship matrix for genotyped animals, and $G$ is a genomic relationship matrix. The genomic matrix can be created following [87] as:

$$
G=Z D Z^{\prime} q
$$

Where, $Z$ is a matrix of gene content adjusted for allele frequencies; $D$, a weight matrix for SNP (initially $D=\mathrm{I}$ ); and $\mathrm{q}$, a weighting/normalizing factor. According to Vitezica et al. [88], this factor can be derived by ensuring that the average diagonal in $G$ is close to that of $A_{22}$. The SNP effects and weights for GWAS were derived as follows [21]:

1. Let $\mathrm{D}=\mathrm{I}$ in the first step.

2. Calculate

3. Calculate GEBVs for the entire data set using ssGBLUP.
4. Convert GEBVs to SNP effects ${ }^{\mathbf{u}}=\frac{\boldsymbol{\sigma}_{\mathbf{u}}^{2}}{\boldsymbol{\sigma}_{\mathbf{a}}^{2}} \mathbf{D} \mathbf{Z}^{\prime} \mathbf{G} *^{-\mathbf{1}} \hat{\mathbf{a}}_{\mathbf{g}}=\mathbf{D} \mathbf{Z}^{\prime}$ $\left[\mathbf{Z D Z}^{\prime}\right]^{-\mathbf{1}} \hat{\mathbf{a}}_{\mathbf{g}}$, where $\hat{\mathbf{a}}_{\mathbf{g}}$ is the GEBV of the animals which were also genotyped.

5. Calculate the weight for each SNP: $d_{i}=\hat{u}_{i}^{2} 2 p_{i}\left(1-p_{i}\right)$, where $i$ is the $\mathrm{i}$-th SNP

6. Normalized SNP weight to remain the total genetic variance constant.

7. Loop to 2.

The SNP weights were calculated iteratively looping trough steps 4-6. The iterations increase the weights of SNP with large effects and decrease those with small effects.

The percentage of genetic variance explained by i-th region was calculated by:

$$
\frac{\operatorname{Var}\left(a_{i}\right)}{\sigma_{a}^{2}}=\times 100=\frac{\operatorname{Var}\left(\sum_{j=1}^{10} Z_{j} \hat{u}_{j}\right)}{\sigma_{a}^{2}} \times 100
$$

Where, $a_{i}$ is genetic value of the $i$-th region that consists of continuous 10 adjacent SNPs, $\sigma_{a}^{2}$, the total genetic variance; $Z_{j}$, the vector of gene content of the $j$-th SNP for all individuals; and $\hat{\mathrm{u}}_{\mathrm{j}}$, marker effect of the $i$-th SNP within the $i$-th region.

\section{Quantitative genetic analysis}

The contemporary groups included animals born on the same farm and year, and from the same management group at yearling. The contemporary groups that contained less than three observations and those that deviated 3 standard deviations from the mean of that group were eliminated. The model used for the variance component estimation included random additive direct genetic effect, the fixed effect of the contemporary groups, and the animal's slaughter age as a covariable (linear and quadratic effect).

The variances components and genetic parameters were estimated using the Bayesian inference [89], considering a linear animal model (ssGBLUP), and the GIBBS2F90 computer programs [32, 33]. The statistical model can be represented by the following matrix form:

$$
y=X \beta+Z a+e
$$

where: $y$ is the vector of observations; $\beta$, the vector of fixed effects; $a$, the vector of direct additive genetic effects; $X$, the known incidence matrix; $Z$, the incidence matrix of the random additive direct genetic effect (associates vector $\beta$ with vector $y$ ); and $e$, the vector of the residual 
effect. The priori distributions of vectors $y, a$ and $e$ were given by:

$$
\begin{aligned}
& \mathrm{y} \sim M V N(X \beta+Z a) \\
& \mathrm{a} \mid G \sim M V N(0, H \otimes G) \\
& \mathrm{e} \mid R \sim M V N(0, I \otimes R)
\end{aligned}
$$

Where: $H$ is the matrix of kinship coefficients between animals obtained from the single-step analyses; $R$, the matrix of residual variance; I, the identity matrix; G, matrix of additive genetic variance; and, $\otimes$, the Kronecke product. The prior distribution of variance components of the genetic and residual effects was an inverted Wishart. Uniform initial distribution was defined for fixed effects.

The analyses generated chain lengths of 1,000,000 interactions, where the first 80,000 interactions were discarded. To estimate the parameters, the samples were stored at every 100 cycles, building samples with 800,000 samples. The data convergence was verified with the graphical evaluation of sampled values versus interactions according to the criteria proposed by several authors [90-92], using the Bayesian Output Analysis (BOA) of the R 2.9.0 software [93].

\section{Searching for genes}

The segments that explained values equal to or greater than $1 \%$ of the additive genetic variance were selected to determine the possible QTL regions. The selected segments were identified and located in the bovine genome by surveying the database available in the "National Center for Biotechnology Information" [94] in UMD3.1 version of the bovine genome and Ensembl Genome Browser [95]. In these databanks, it was possible to identify segments located within or close to genes that could explain the variability in the expression of such traits. The classification of genes regarding their biological function was performed on the website "The Database for Annotation, Visualization and Integrated Discovery (DAVID) v. 6.7" [96]. Whereas the already described QTLs were researched on the AnimalQTLdb website [97].

\section{Availability of supporting data}

The data sets supporting the results of this article are included within the article and its additional files.

\section{Additional file}

Additional file 1: Manhattan plot of the genome-wide association study for fatty acids in Nellore. The $\mathrm{X}$-axis represents the chromosomes, and the $\mathrm{Y}$-axis shows the proportion of genetic variance explained by windows of 10 adjacent SNPs in the following 18 fatty acids: arachidonic, CLA-cis, CLA-trans, docosahexaenoic, eicosatrienoic,myristoleic, MUFA, PUFA, myristic, n6:n3, oleic, omega-3, palmitic, stearic, palmitoleic and PUFA:SFA ratio in Nellore. (ZIP 1395 kb)

\section{Abbreviations}

BTA: Bos Taurus chromosome.; CLA: Conjugated linoleic acid; FA: Fatty acid; GEBVs: Genomic estimated breeding values; GO: Gene ontology; GWAS: Genomewide association study; MAF: minor allele frequency; MUFA: sum of monounsaturated fatty acids; n-3: Sum of omega 3 acids; n-6: Sum of omega 6 acids; PCG: Putative candidate gene; PUFA: Sum of polyunsaturated fatty acids; QTL: Quantitative trait loci; SFA: Sum of saturated fatty acids; SNP: Single nucleotide polymorphism; UK: United Kingdom.

\section{Competing interests}

The authors declare that they have no competing interests.

\section{Authors' contributions}

MVAL, FLBF, CA, MPB, ASCP and FB conceived and designed the experiment: MVAL, MPB, HLJC, FLBF, CA, AMF, LFM, JMF, DMG, RLT, RE, GMFC and HN performed the experiments; MVAL, HN, ASCP, SD, IA and FB did analysis and interpretation of results; RMOS, MVAL, ACSP and FB drafted the manuscript. All authors read and approved the final manuscript.

\section{Acknowledgments}

MVA Lemos, (FAPESP, Fundação de Amparo à Pesquisa do Estado de São Paulo). HLJ Chiaia, MP Berton, FLB Feitosa received scholarships from the Coordination Office for Advancement of University-level Personnel (CAPES; Coordenação de Aperfeiçoamento de Pessoal de Nível Superior) in conjunction with the Postgraduate Program on Genetics and Animal Breeding, Faculdade de Ciências Agrárias e Veterinárias, Universidade Estadual Paulista (FCAV, UNESP). F Baldi (FAPESP, Fundação de Amparo à Pesquisa do Estado de São Paulo grant \#2011/21241-0). Lucia G. Albuquerque (FAPESP, Fundação de Amparo à Pesquisa do Estado de São Paulo grant \#2009/16118-5).

\section{Author details}

${ }^{1}$ Departamento de Zootecnia, Faculdade de Ciências Agrárias e Veterinárias, Universidade Estadual Paulista, Via de acesso Prof. Paulo Donato Castellane, s/no, CEP 14884-900 Jaboticabal, São Paulo, Brazil. Departamento de Nutrição e Produção Animal, Faculdade de Medicina Veterinária e Zootecnia, Universidade de São Paulo, Avenida Duque de Caxias Norte, 225, CEP 13635-900 Pirassununga, São Paulo, Brazil. ${ }^{3}$ Department of Animal and Veterinary Science, Clemson University, Clemson, SC, USA. ${ }^{4}$ Department of Animal Breeding Montevideo, National Institute of Agricultural Research of Uruguayy, Montevideo, Uruguay.

Received: 19 November 2015 Accepted: 23 February 2016 Published online: 09 March 2016

\section{References}

1. Katan MB, Zoock PM, Mensink RP. Effects of fats and fatty acids on blood lipids in humans: an overview. Am J Clin Nutr. 1994;60:1017-22.

2. Lawrie RA. Ciência da carne. 6th ed. Porto Alegre: Artmed; 2005. p. 384.

3. Rossato LV, Bressan MC, Rodrigues EC, Carolino MDC, Bessa RJB, Alves SPP Composição lipídica de carne bovina de grupos genéticos taurinos e zebuínos terminados em confinamento. R Bras Zootec. 2009;38:1841-6.

4. Duckett $\mathrm{S}$. Changes in dietary regime impact fatty acid profile of beef, Focus on feedlot. Lincoln: Bif symposium; 2014.

5. Pensel N. The future of red meat in human diets. Nutrit Abstrac Rev (Series A). 1998:68:1-4. Farnham Royal.

6. Simopoulos. Essential fatty acids in health and chronic disease. Am J Clin Nutr. 1999;70(3):560s-9.

7. French P, Stanton C, Lawless F. Fatty acid composition, including conjugated linoleic acid, of intramuscular fat from steers offered grazed grass, grass silage or concentrate based diets. J Anim Sci. 2000;78:2849-55.

8. Tamminga S, Doreau M. Lipids and rumen digestion. In: Jouany JP, editor. Rumen microbial metabolism and ruminant digestion. Paris: INRA; 1991. p. 151-64.

9. Ip C. Review of the effects of trans fatty acids, oleic acid, n-3 polyunsaturated fatty acids, and conjugated linoleic acid on mammary carcinogenesis in animals. Am J Clin Nutr. 1997;66:1523-9.

10. Dugan MER, Aldai N, Aalhus JL, Rolland DC, Kramer JKG. Review: Trans-forming beef to provide healthier fatty acid profiles. Can J Anim Sci. 2011;91:54-6.

11. Faucitano L, Chouinard PY, Fortin J, Mandell IB, Lafreniere C, Girard CL, Berthiaume R. Comparison of alternative beef production systems based on forage finishing or grain-forage diets with or without growth promotants: 2. 
Meat quality, fatty acid composition, and overall palatability. J Anim Sci. 2008;86:1678-89.

12. De Smet S, Raes K, Demeyer D. Meat fatty acid composition as affected by fatness and genetic factors: a review. Anim Res. 2004;53:81-98.

13. Cesar ASM, Regitano LCA, Tullio RR, Lanna DPD, Nassu RT, Mudado MA, Oliveira PSN, Do Nascimento ML, Chaves AS, Alencar MM, Sonstegard TS, Garrick DJ, Reecy JM and Coutinho LL. Genome-wide association study for intramuscular fat deposition and composition in Nellore cattle. BMC Genet. 2014;15.

14. Ishii A, Yamaji K, Uemoto Y, Sasago N, Kobayashi E, Kobayashi N, Matsuhashi T, Maruyama S, Matsumoto H, Sasazaki S, Mannen H. Genomewide association study for fatty acid composition in Japanese Black cattle. J Anim Sci. 2013;84(10):675-82.

15. Sevane N, Armstrong E, Wiener P, Pong Wong R, Dunner S, Consortium GQ. Polymorphisms in twelve candidate genes are associated with growth, muscle lipid profile and meat quality traits in eleven European cattle breeds. Mol Biol Rep. 2014;41:4721-31.

16. Saatchi M, Garrick DJ, Tait Jr RG, Mayes MS, Drewnoski M, Schoonmaker J, Diaz C, Beitz DC, Reecy JM. Genome-wide association and prediction of direct genomic breeding values for composition of fatty acids in Angus beef cattlea. BMC Genomics. 2013;14(1):730.

17. Chen CY, Misztal I, Aguilar I, Legarra A, Muir WM. Effect of different genomic relationship matrices on accuracy and scale. J Anim Sci. 2011;89:2673-9.

18. Ahlberg CM, Schiermiester NL, Howard JT, Calkins CR, Spangler ML. Genome wide association study of cholesterol and poly- and monounsaturated fatty acids, protein, and mineral content of beef from crossbred cattle. Meat Sci. 2014;98:804-14.

19. Mcclure MC, Ramey HR, Rolf MM, Mckay SD, Decker JE, Chapple RH, and Taylor JF. Genomewide association analysis for quantitative trait loci influencing Warner-Bratzler shear force in five taurine cattle breeds. Anim Genet. 2012:43:662-73.

20. Zeng J, Pszczola M, Wolc A, Strabel T, Fernando RL, Garrick DJ, and Dekkers JCM. Genomic breeding value prediction and QTL mapping of QTLMAS2011 data using Bayesian and GBLUP methods. BMC Proc. 2012;6 Suppl 2:S7.

21. Wang H, Misztal I, Aguilar I, Legarra A, Muir WM. Genome-wide association mapping including phenotypes from relatives without genotypes. Genet Res. 2012;94:73-83.

22. Misztal I, Tsuruta S, Aguilar I, Legarra A, VanRaden PM, Lawlor TJ. Methods to approximate reliabilities in single-step genomic evaluation. J Dairy Sci. 2013:96:647-54.

23. Prado IN, Moreira FB, Matsushita M, Souza NE. Longissimusdorsi fatty acids composition of Bosindicus and Bosindicus $\times$ Bostaurus crossbred steers finished in pasture. Braz Arch Biol Technol. 2003:46:599-606.

24. Kelly MJ, Tume RK, Newman S, Thompson JM. Genetic variation in fatty acid composition of subcutaneous fat in cattle. J Comp Anim Prod Sci. 2013;53:129-33.

25. Woollett AL, Spady KD, Dietschy MJ. Saturated and unsaturated fatty acids independently regulate low-density lipoprotein receptor activity and production rate. J Lipid Res. 1992;33:77-88.

26. Pitchford WS, Deland MPB, Siebert BD, Malau-Aduli AE, Bottema CDK. Genetic variation in fatness and fatty acid composition of crossbred cattle. J Anim Sci. 2002;80:2825-32.

27. Wood JD, Enser M. Factors influencing fatty acids in meat and the role of antioxidants in improving meat quality. Br J Nutr. 1997:78:49-60.

28. Departament of Healt. Nutritional Aspects of Cardiovascular Disease, Report on Health and Social Subjects n. 46. London: H.M. Stationery Office; 1994.

29. Lorgeril M, Renaud S, Mamelle N, Salen P, Martin JL, Monjaud I, et al. Mediterranean alpha-linolenic acid rich diet in secondary prevention of coronary heart disease. Lancet. 1994;343(8911):1454-9.

30. Simopoulos AP. The importance of the ratio of omega-6/omega-3 essential fatty acids. Biomed Pharmacother. 2002;56:365-79.

31. Enser M, Hallett K, Hewitt B, Fursey GAJ, Wood JD. Fatty acid content and composition of English beef, lamb and pork at retail. Meat Sci. 1996;42:443-56.

32. Geweke J. Evaluating the accuracy of sampling-based approaches to the calculation of posterior moments. In: Bernardo JM, Berger J, Dawid AP, Smith AFM, editors. Bayesian Statistics 4. Oxford: Oxford University Press; 1992. p. 169-93.

33. Heidelberger P, Welch PD. Simulation run length control in the presence of an initial transient. Oper Res. 1983;31:1109-44.

34. Nogi T, Honda T, Mukai F, Okagaki T, Oyama K. Heritabilities and genetic correlations of fatty acid compositions in Longissimus muscle lipid with carcass traits in Japanese Black cattle. J Anim Sci. 2011;89:615-21.
35. Tait R, Zhang $S$, Knight T, Bormann JM, Beitz D, Reecy J. Heritability estimates for fatty acid quantity in Angus beef. J Anim Sci. 2007;85:58.

36. Inoue K, Kobayashi M, Shoji N, Kato K. Genetic parameters for fatty acid composition and feed efficiency traits in Japanese Black cattle. Animal. 2011;5:987-94.

37. Ekine-Dzivenu C, Chen L, Vinsky M, Aldai N, Dugan MER, Mcallister TA, Wang Z, Okine E, and Li C. Estimates of genetic parameters for fatty acids in brisket adipose tissue of Canadian commercial crossbred beef steers. Meat Sci. 2014:96:1517-26.

38. Malau-Aduli AEO, Edriss MA, Siebert BD, Bottema CDK, Deland MPB, Pitchford WS. Estimates of genetic parameters for triacylglycerol fatty acids in beef cattle at weaning and slaughter. J Anim Physiol Anim Nutr. 2000;83:169-80.

39. Silva RG, Prado IN, Matsushita M, Souza NE. Dietary effects on muscle fatty acid composition of finished heifers. Pesqui Agropec Bras. 2002;37:95-101.

40. Kubo T, Yamamoto H, Lockwood WW, Valencia I, Soh J, Peyton M, Jida M, Otani H, Fujii T, Ouchida M, Takigawa N, Kiura K, Shimizu K, Date H, Minna JD,Varella-Garcia M, Lam WL, Gazdar AF, Toyooka S. MET gene amplification or EGFR mutation activate MET in lung cancers untreated with EGFR tyrosine kinase inhibitors. Int J Cancer. 2009;15:1778-84.

41. Sanoudou D, Duka A, Drosatos K, Hayes KC, Zannis VI. Role of Esrrg in the fibrate-mediated regulation of lipid metabolism genes in human ApoA-I transgenic mice. Pharmacogenomics J. 2010;10:165-79.

42. Guyton AC, Hall JE. Tratado De Fisiologia Médica 10. Ed. Rj. Guanabara Koogan, 2002; 973 p.

43. Sharma NK, Langberg KA, Mondal AK, Das SK. phospholipid biosynthesis genes and susceptibility to obesity: analysis of expression and polymorphisms. Plos one. 2013;8(5), e65303.

44. Hwang J-I, Oh Y-S, Shin K-J, Kim H, Ryu SH, Suh PG. Molecular cloning and characterization of a novel phopholipase C. PL Ceta Biochem J. 2005;389:181-6.

45. Kim HA, Kwon NS, Baek KJ, Kim DS, Yun HY. Leucine-rich glioma inactivated 3 and tumor necrosis factor-a regulate mutually through NF-jB. Cytokine. 2015;72:220-3.

46. Petrovic V, Costa RH, Lau LF, Raychaudhuri P, Tyner AL. FoxM1 regulates growth factor-induced expression of Kinase-interacting stathmin (KIS) to promote cell cycle progression. J Biol Chem. 2008;283:453-60.

47. Hu WF, Chahrour MH, Walsh CA. The diverse genetic landscape of neuro developmental disorders. Annu Rev Genomics Hum Genet. 2014;15:195-213.

48. Marijanovic Z, Laubner D, Moller G, Gege C, Husen B, Adamski J, Breitling R. Closing the gap: identification of human 3-ketosteroid reductase, the last unknown enzyme of mammalian cholesterol biosynthesis. Epub. 2003;17(9):1715-25.

49. D'Andre HC, Paul W, Shen X, Jia X, Zhang R, Liang Sun L, and Zhang X. Identification and characterization of genes that control fat deposition in chickens. J Anim Sci Biotech. 2013;4:43.

50. MacKenzie SM, Huda SS, Sattar N, Fraser R, Connell JMC, Davies E. Depot-specific steroidogenic gene transcription in human adipose tissue. Clin Endocrinol. 2008:69:848-54

51. Hamouda N, Trana V, Croteaua LP, Kaniaa A, Côtéa JF. G-protein coupled receptor BAl3 promotes myoblast fusion in vertebrates. PNAS. 2014;111: $3745-50$.

52. Lutsenko $S$. Modifying factors and phenotypic diversity in Wilson's disease. Ann N Y Acad Sci. 2014;1315:56-63.

53. Persson B, Kallberg Y, Bray JE, Bruford E, Dellaporta SL, Favia AD, Duarte RG, Jörnvall H, Kavanagh KL, Kedishvili N, Kisiela M, Maser E, Mindnich R,Orchard S, Penning TM, Thornton JM, Adamski J, Oppermann U. The SDR (short-chain dehydrogenase/reductase and related enzymes) nomenclature initiative. Chem Biol Interact. 2009;178(1-3):94-8.

54. Bartuma H, Nord KH, Macchia G, Isaksson M, Nilsson J, Domanski HA, Mandahl N, Mertens F. Gene expression and single nucleotide polymorphism array analyses of spindle cell lipomas and conventional lipomas with 13q14 Deletion. Genes Chromosom Cancer. 2011;50:619-32.

55. Kwofie MA, Skowronski J. Specific Recognition of Rac2 and Cdc42 by DOCK2 and DOCK9 Guanine Nucleotide Exchange Factors. J Biol Chem. 2008:283:3088-96.

56. Nishikimi A, Fukuhara H, Su W, Hongu T, Takasuga S, Mihara H, Cao Q, Sanematsu F, Kanai M, Hasegawa H,Tanaka Y, Shibasaki M,Kanaho Y, Sasaki T, Frohman MA, Fukui Y.. Sequential regulation of DOCK2 Dynamics by two phospholipids during neutrophil chemotaxis. Science. 2009:324:384-7.

57. Miegueu P, St-Pierre DH, Mukonda NM, Lapointe M, Cianflone K. Amylin stimulates fatty acid esterification in 3T3-L1 adipocytes. Mol Cell Endocrinol. 2013;366:99-107. 
58. Magee DA, Sikora KM, Berkowicz EW, Berry DP, Howard DJ, Mullen MP, Evans RD, Spillane C, MacHugh DE. DNA sequence polymorphisms in a panel of eight candidate bovine imprinted genes and their association with performance traits in Irish Holstein-Friesian cattle. BMC Genet. 2010;11:93.

59. Kanai $Y$, Hediger MA. The glutamate/neutral amino acid transporter family SLC1: Molecular, physiological and pharmacological aspects. Pflugers Arch Eur J Physiol. 2004;447:469-79.

60. Giaccia AJ, Denko N, MacLaren R, Mirman D, Waldren C, Hart I, Stamato TD. Human chromosome 5 complements the DNA double-strand break-repair deficiency and gamma-ray sensitivity of the XR-1 hamster variant. Am J Hum Genet. 1990;47(3):459-69.

61. Tabassum R, Chauhan G, Dwivedi OP, Mahajan A, Jaiswal A, Kaur I, Bandesh K, Singh T, Mathai BJ, Pandey Y, Chidambaram M, Sharma A, Chavali S,Sengupta S, Ramakrishnan L, Venkatesh P, Aggarwal SK, Ghosh S, Prabhakaran D, Srinath RK, Saxena M, Banerjee M, Mathur S, Bhansali A, Shah VN,Madhu SV, Marwaha RK, Basu A, Scaria V, McCarthy MI; DIAGRAM; INDICO, Venkatesan R, Mohan V, Tandon N, Bharadwaj D. Genome wide association study for type 2 diabetes in Indians identifies a new susceptibility locus at 2q21. Diabetes. 2013;62(3):977-86.

62. Schmitz G, Langmann T. Structure, function and regulation of the $A B C 1$ gene product. Curr Opin Lipidol. 2001;12(2):129-40.

63. Ye D, Hoekstra M, Out R, Meurs I, Kruijt JK, Hildebrand RB, Van Berkel TJC, Van Eck M. Hepatic cell-specific ATP-binding cassette (ABC) transporter profiling identifies putative novel candidates for lipid homeostasis in mice. Atherosclerosis. 2008:196:650-8.

64. Wenzel JJ, Kaminski WE, Piehler A, Heimerl S, Langmann T, Schmitz G. ABCA10, a novel cholesterol-regulated ABCA6-like ABC transporter. Biochem Biophys Res Commun. 2003;306:1089-98.

65. Ryu J, Kim Y, Kim C, Kim J, Lee C. Association of bovine carcass phenotypes with genes in an adaptive thermogenesis pathway. Mol Biol Rep. 2012;39:1441-5

66. Rothammer S, Seichter D, Förster M, Medugorac I. A genome-wide scan for signatures of differential artificial selection in ten cattle breeds. BMC Genomics. 2013;14:908.

67. Muhn F, Klopocki E, Graul-Neumann L, Uhrig S, Colley A, Castori M, Lankes E, Henn W, Gruber-Sedlmayr U, Seifert W, Horn D. Novel mutations of the PRKAR1A gene in patients with acrodysostosis. Clin Genet. 2013;6:531-8. doi:10.1111/cge.12106.

68. London E, Rothenbuhler A, Lodish M, Gourgari E, Keil M, Lyssikatos C, Sierra MDL, Patronas N, Nesterova M, Stratakis CA. Differences in adiposity in cushing syndrome caused by PRKAR1A Mutations: clues for the role of cyclic amp signaling in obesity and diagnostic implications. J Clin Endocrinol Metab. 2014:99(2):E303-10

69. Leonard AE, Bobik EG, Dorado J, Kroeger PE, Chuang LT, Thurmond JM, Parker-Barnes JM, Das T, Huang YS, Mukerji P. Cloning of a human CDNA encoding a novel enzyme involved in the elongation of long-chain polyunsaturated fatty acids. Biochem J. 2000:15(350 Pt 3):765-70.

70. Green CD, Ozguden-Akkoc CG, Wang Y, Jump DB, Olson LK. Role of fatty acid elongases in determination of de novo synthesized monounsaturated fatty acid species. J Lipid Res. 2010;51:1871-7. doi:10.1194/jlr.M004747.

71. Tamura K, Makino A, Hullin-Matsuda F, Kobayashi T, Furihata M, Chung S, Ashida S, Miki T, Fujioka T, Shuin T, Nakamura Y, Nakagawa H. Novel lipogenic enzyme ELOVL7 is involved in prostate cancer growth through saturated long-chain fatty acid metabolism. Cancer Res. 2009;69:8133-40.

72. Chen HC, Lin WC, Tsay YG, Lee SC, Chang CJ. An RNA helicase, DDX1, interacting with poly(A) RNA and heterogeneous nuclear ribonucleoprotein. KJ Biol Chem. 2002;277(43):40403-9.

73. Buchner DA, Geisinger JM, Glazebrook PA, Morgan MG, Spiezio SH, Kaiyala KJ, Schwartz MW, Sakurai T, Furley AJ, Kunze DL, Croniger CM, Nadeau JH. The juxtaparanodal proteins CNTNAP2 and TAG1 regulate diet-induced obesity. Mamm Genome. 2012;23:431-42

74. Yang Y, Lu Y, Espejo A, Wu J, Xu W, Liang S, Bedford MT. TDRD3 is an effector molecule for arginine-methylated histone marks. Mol Cell. 2010;40(6):1016-23.

75. Jacobson SG, Cideciyan AV, Aleman TS, Sumaroka A, Roman AJ, Gardner LM, Prosser HM, Mishra M, Bech-Hansen NT, Herrera W, Schwartz SB, Liu XZ,Kimberling WJ, Steel KP, Williams DS. Usher syndromes due to MYO7A, PCDH15, USH2A or GPR98 mutations share retinal disease mechanism. Hum Mol Genet. 2008;17(15):2405-15.
76. Oh MJ, van Agthoven T, Choi JE, Jeong YJ, Chung YH, Kim CM, Jhun BH. BCAR3 regulates EGF-induced DNA synthesis in normal human breast MCF-12A cells. Biochem Biophys Res Commun. 2008.

77. Kemper KE, Goddard ME. Understanding and predicting complex traits: knowledge from cattle. Hum Mol Genet. 2012;21(R1):R45-51.

78. Wang H, Misztal I, Aguilar I, Legarra A, Fernando RL, Vitezica Z, Okimoto R, Wing T, Hawken R, Muir WM. Genome-wide association mapping including phenotypes from relatives without genotypes in a single-step (ssGWAS) for 6-week body weight in broiler chicken. Genet Res. 2014;94:73-83.

79. Zhang S, Knight TJ, Reecy JM, Beitz DC. DNA polymorphisms in bovine fatty acid synthase are associated with beef fatty acid composition. Anim Genet. 2008;39(1):62-70.

80. Jakobsson A, Westerberg R, Jacobsson A. Fatty acid elongases in mammals: their regulation and roles in metabolism. Prog Lipid Res. 2006;45:237-49. doi:10.1016/j.plipres.2006.01.004.

81. Bonet ML, Ribot J, Palou A. Lipid metabolism in mammalian tissues and its control by retinoic acid. Biochim Biophys Acta. 1821;2012:177-89. doi:10.1016/j.bbalip.2011.06.001.

82. Dunner S, Sevane N, Garcia D, Levéziel H, Williams JL, Mangin B, Valentini A. Genes involved in muscle lipid composition in 15 European Bos taurus breeds. Anim Genet. 2013:44(5):493-501.

83. Folch J, Lees M, Sloane-Stanley GH. A simple method for the isolation and purification of lipids from animal tissues. J BiolChem. 1957;226:497-509.

84. Bligh EG, Dyer WJ. A rapid method for total lipid extraction and purification. CanJBiochemPhysiol. 1959;37:911-7.

85. Kramer JKG, Fellner V, Dugan MER, Sauer FD, Mossoba MM, Yurawecz MP. Evaluating acid and base catalysts in the methylation of milk and rumen and rumen fatty acids with special emphasis on conjugated dienes and total trans fatty acids. Lipids. 1997;32:1219-28.

86. Aguilar I, Misztal I, Johnson DL, Legarra A, Tsuruta S, Lawlor TJ. A unified approach to utilize phenotypic, full pedigree, and genomic information for genetic evaluation of Holstein final score. J Dairy Sci. 2010;93:743-52.

87. Vanraden PM, Van Tassell CP, Wiggans GR, Sonstegard TS, Schnabel RD, Taylor JF, Schenkel FS. Invited review: Reliability of genomic predictions for North American Holstein bulls. J Dairy Sci. 2009;92:16-24.

88. Vitezica ZG, Aguilar I, Misztal I, Legarra A. Bias in genomic predictions for populations under selection. Genet Res Camb. 2011;93:357-66.

89. Gianola D, Fernando RL. Bayesian methods in animal breeding theory. J Anim Sci. 1986;63:217-44

90. Misztal I, Tsuruta S, Strabel T, Auvray B, Druet T, Lee DH. BLUPF90 and related programs (BGF90). Monteplier: Proceedings... 7th World Congress on Genetics Applied to Livestock Production; 2002. p. 07. CD-ROM communication

91. Aguilar I, Misztal I, Tsuruta S, Wiggans GR, Lawlor TJ. Multiple trait genomic evaluation of conception rate in Holsteins. J Dairy Sci. 2011;94:2621-4.

92. Raftery AE, Lewis SM. How many iterations in the Gibbs sampler. In: Bernardo JM et al., editors. Bayesian Statistics 4. Oxford: Oxford University Press; 1992. p. 763-73.

93. R Development Core Team. A language and environment for statistical computing. Vienna: R Foundation for Statistical Computing; 2015. http://www.R-project.org.

94. National Center for Biotechnology Information. U.S. National Library of Medicine. Rockville: NCBl; 2015. http://www.ncbi.nlm.nih.gov/projects/ mapview/map_search.cgi?taxid=9913\&build=104.0. Accessed 2 Nov 2015.

95. Flicek P, Ahmed I, Amode MR, Barrell D, Beal K, Brent S, Carvalho-Silva D, Clapham P, Coates G, Fairley S, Fitzgerald S, Gil L, García-Girón C, Gordon L, Hourlier T, Hunt S, Juettemann T, Kähäri AK, Keenan S, Komorowska M, Kulesha E, Longden I, Maurel T, McLaren WM, Muffato M, Nag R, Overduin B, Pignatelli M, Pritchard B, Pritchard E, et al. Ensembl 2013. Nucleic Acids Res. 2013:41(Database issue):D48-55.

96. da Huang W, Sherman BT, Lempicki RA. Bioinformatics enrichment tools: paths toward the comprehensive functional analysis of large gene lists. Nucleic Acids Res. 2009;37(1):1-13.

97. Hu ZL, Park CA, Wu XL, Reecy JM. Animal QTLdb: an improved database tool for livestock animal QTL/association data dissemination in the postgenome era. Nucleic Acids Res. 2013;41(Database issue):D871-9. 